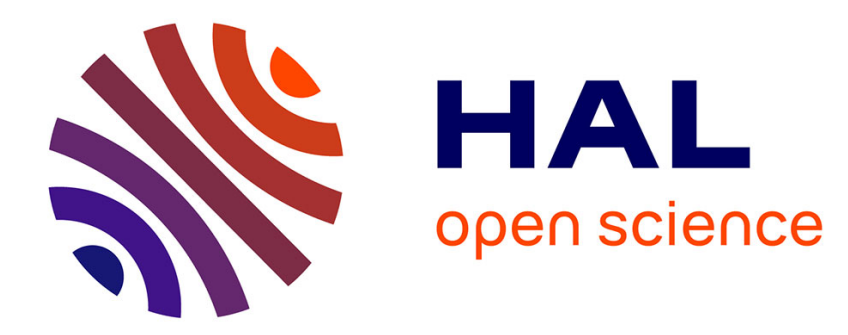

\title{
Disclosure, ownership structure and bank risk: Evidence from Asia
}

Bowo Setiyono, Amine Tarazi

\section{To cite this version:}

Bowo Setiyono, Amine Tarazi. Disclosure, ownership structure and bank risk: Evidence from Asia. 2014. hal-00947590

\section{HAL Id: hal-00947590 \\ https://hal-unilim.archives-ouvertes.fr/hal-00947590}

Preprint submitted on 17 Feb 2014

HAL is a multi-disciplinary open access archive for the deposit and dissemination of scientific research documents, whether they are published or not. The documents may come from teaching and research institutions in France or abroad, or from public or private research centers.
L'archive ouverte pluridisciplinaire HAL, est destinée au dépôt et à la diffusion de documents scientifiques de niveau recherche, publiés ou non, émanant des établissements d'enseignement et de recherche français ou étrangers, des laboratoires publics ou privés. 


\title{
Disclosure, ownership structure and bank risk: Evidence from Asia
}

\author{
Bowo Setiyono $^{\mathrm{a} 1}$ and Amine Tarazi ${ }^{\mathrm{a}}$ \\ ${ }^{a}$ Université de Limoges, LAPE, 5 rue Félix Eboué, 87031 Limoges Cedex, France
}

This draft: February 13, 2014

Please do not quote without the permission of the authors

\begin{abstract}
We investigate the impact of the interaction of disclosure and ownership structure on bank risk. Using a sample of 209 commercial banks from Asia during the 2004-2010 period, we find that disclosure is negatively associated with income volatility and that such an impact is stronger in the presence of block holders and institutional ownership and weaker with insider or government ownership. Our results also provide evidence that better disclosure ensures greater stability as measured by individual bank default risk. Furthermore, a deeper investigation shows that disclosure on income statement, loans, other earning assets, deposits, and memo lines plays a stronger role in limiting risk than disclosure on non-deposit liabilities.
\end{abstract}

JEL classification: G21 G28 G32

Keywords : Bank risk, disclosure index, bank ownership

${ }^{1}$ Corresponding author. Tel: + 33555149251

E-mail address : bowo.setiyono@etu.unilim.fr (B. Setiyono) 


\section{Introduction}

The 2007-2008 global financial crisis has highlighted the need to enhance sound corporate governance principles. As such, a lot of emphasis has been put on improving transparency for firms in general and specifically for financial institutions. The new bank regulatory framework (Basel III) ${ }^{1}$ imposes more stringent disclosure requirements to improve the ability of bank stakeholders to assess the riskiness of the institutions in which they are involved. However, whether better disclosure is actually beneficial remains an open question because too much information might also exacerbate the concerns of creditors and hence contribute to more instability (Hyytinen \& Takalo, 2002; Nier, 2005; Tadesse, 2006). In this paper we investigate whether disclosure identically impacts the riskiness of banks with different ownership profiles and consider the differential impact of disclosure on various balance sheet and income statement items.

Some studies argue that inadequate control mechanisms and asymmetric information lead to higher risk-taking in banks (Fama and Jensen, 1983; Cebenoyan et al, 1999). Such works claim that disclosure is expected to mitigate asymmetric information and hence stakeholders would be in more control with regard to bank risktaking. Similarly, Baumann and Nier (2004) observe that banks with a higher level of disclosure, as measured by a disclosure composite index, exhibit a lower stock price volatility. They argue that increasing the amount of disclosure would mitigate the heterogeneity of information on the bank's current conditions across different shareholders. In another study, Cordella and Yeyati (1998), as confirmed by Boot and Schmeits (2000), find that banks with greater disclosure are likely to have a lower default risk at equilibrium. However, requiring disclosure of more information may impose costs on banks and possibly overemphasize small problems that could by contagion affect the banking system as a whole (Kaufman and Scott, 2003; Tadesse, 2006). In this regard, more disclosure could make the banking system more fragile.

The level of bank disclosure is presumably related to bank characteristics including ownership type, governance and therefore the potential conflicts of interest among parties. The conflicts of interests between managers, shareholders and other stakeholders have been widely documented since the seminal work of Jensen and

\footnotetext{
${ }^{1}$ The Basel III Accord sets the revised disclosure requirements of qualitative and quantitative aspects of risk management, capital adequacy and underlying risk metrics. It also requires the disclosure of securitization exposures and off-balance sheet vehicles (BCBS, 2010, 2011).
} 
Meckling (1976). Further studies suggest that when owners' control on management is weak due to lack of market discipline, managers are inclined to pursue their own interests instead of those of shareholders (Fama, 1980; Fama \& Jensen, 1983; Shleifer and Vishny (1997). In the banking sector, such issues are further complicated because more parties are involved in the so-called multi-relationship-based transactions (Wilson et al, 2010). Apart from shareholders, debt holders and managers, deposit insurers and regulators are also involved in the process with their own interests which in many cases possibly conflict with each other. Various factors such as bank balance sheet opacity (Diamond, 1984; Morgan, 2002), low level of depositor education, limited protection of minority shareholders particularly in emerging markets (King and Levine $1993 \mathrm{a}, \mathrm{b}$; Levine 1997, Wilson et al, 2010) also play an important role.

The banking sector is subject to numerous regulations aiming to protect the rights of depositors, shareholders and to make banks operate more efficiently. Accordingly, bank risk-taking behavior is supposed to be within tolerable levels while those aforementioned factors persistently interact with each other. Since many parties participate in bank activities, it is expected that other ownership characteristics namely institutional ownership, government ownership, blockholder ownership and its concentration would also affect bank risk (Angkinand \& Wihlborg, 2010, Barry et al., 2011). With regard to bank ownership, Saunders et al. (1990) have shown that stockholder-controlled banks in the US take more risk than manager-controlled banks because stockholders can diversify their investment whereas managers' wealth is largely composed of non-diversifiable human capital. However, some authors show that the relationship between managerial ownership and bank risk-taking is not monotonic (e.g., Brewer and Saidenberg 1996; Demsetz et al., 1997). Bank risk initially decreases with higher managerial ownership and then starts increasing. Brewer and Saidenberg (1996) argue that such a U-shaped (i.e. convex) relationship is due to the interplay of two opposing factors, managerial risk-aversion/ entrenchment and moral hazard problems, at different levels of managerial ownership. A study by Gorton and Rosen (1995), however, finds an inverted U-shaped relationship (i.e. concave). Further, studies in the US have also found that banks exhibit a greater incentive for risk-taking than other institutions in the financial sector (see Cordell et al., 1993; Esty, 1997; Karels \& McClatchey, 1999). Previous studies (e.g. Ciancanelli and Gonzalez, 2000; Levine, 2004) argue that the agency problem in the banking sector is more 
complex than in other sectors. For example, the conflicts of interests may not only occur between owners, managers and lenders but also involve the regulator. Complexity is exacerbated because of the regulator's commitment to act as the lender of the last resort.

In this paper we examine the relationship between disclosure and the risk-taking behavior of Asian banks. Specifically, we investigate whether the amount of disclosure identically impacts bank risk-taking and bank default risk under different ownership profiles. While previous studies have found ownership structure to affect bank risktaking, we look into whether disclosure will impact bank risk-taking differently in the presence of different ownership structure. We hence test whether the ownership structure moderates the disclosure - risk taking relationship. A higher level of disclosure might affect risk differently under different ownership structures because the incentives of shareholders to use the information to effectively monitor the managers will be more or less strong depending on their stakes and the degree of ownership dispersion. We extend the literature in several directions. First, we construct a composite disclosure score using the disclosure index of Baumann and Nier (2004) \& Nier (2005), and decompose it into six sub indices to capture deeper insights on the relationship between disclosure and risk. We are hence able to test the impact of a global composite index but also to go deeper to examine which disclosure components (sub-indices) more effectively affect bank risk. Second, we consider various bank ownership profiles by looking at stakes owned by managers, governments, institutional investors, and block holders or large owners. Managerial ownership, as discussed above, is expected to align the interests of managers and shareholders. Institutional ownership should lead also to better decisions regarding the bank's investment and financing decisions. While the literature on emerging markets mainly considers state ownership and foreign ownership (e.g. Angkinand and Wihlborg (2010)), we rather focus on other types of ownership structures namely insider ownership, institutional ownership and block holding. Third, previous studies have typically paid more attention on non financial firms (see Claessens and Fan, 2002) and few works have focused on how disclosure might alter the relationship between insider ownership and bank risk-taking. Lastly, most of previous studies have essentially looked into financial institutions in developed markets rather than in emerging markets (see Saunders et al, 1990; Lee, Mayers, and Smith, 1997; Garcia-Marco \& Robles-Fernandez, 2008). We 
consider banks operating in emerging economies in Asia which have rapidly grown to play a major role in the global financial system. Furthermore, ownership structure in Asia is far more complex with less widely held institutions and far more pyramidal ownership structures than in Western countries (La Porta et al., 1999; Claessens et al., 2000; Claessens \& Yurtoglu, 2013).

We consider a sample of 209 publicly-listed banks from 11 countries in Asia for the 2004-2010 period and find that a higher disclosure index is significantly and negatively associated with default risk and income volatility. We also find that the impact on income volatility is stronger in the presence of block holders and institutional ownership and weaker with insider or government ownership. Furthermore, a deeper investigation shows that disclosure on loans, other earning assets, deposits, and memo lines plays a stronger role in limiting risk than disclosure on income statements and non-deposit liabilities.

The rest of this paper is organized as follows. The next section offers some conceptual background and presents the hypotheses that we test. Section 3 describes the econometric model and the data. Section 4 presents the results. Finally, section 5 concludes.

\section{Related literature and hypotheses}

Publicly listed firms have to file dozens of reports to capital market authorities. In the case of financial institutions, the demand for disclosure is arguably higher due to their business characteristics (i.e. opaqueness) and potential problems for overall financial stability. Pillar 3 of the revised Basel Accord states that the disclosure requirement on banks is aimed to allow bank owners and regulators to monitor bank activities and to achieve prudential banking practices. While a large body of the literature highlights a positive impact of disclosure on stability, some authors consider it to be questionable.

The demand for disclosure has initially been addressed by Jensen and Meckling (1976) regarding the moral hazard problem due to separation between ownership and control. Because outside shareholders are not involved in day-to-day firm's activities, they require the manager to disclose all relevant information in order to evaluate the firm's performance. In this perspective, an adequate level of disclosure should allow shareholders and potential investors to mitigate the agency problem. For banks more 
specifically, because a large portion of their liabilities are short term, the release of more information is expected to enable better monitoring and prevent higher risktaking that could lead to withdrawals from their short term debt holders (depositors) and/or a higher cost of funding (see Cordella and Yeyati, 1998, Botosan \& Plumlee, 2002; Francis, Khurana, Levine, 2004; Pereira, 2005; Bertay, Demicgüç-Kunt \& Huizinga, 2013). By reducing risk-taking incentives, disclosure of information is also expected to lower the probability of bank failures. Some authors argue that previous banking crises could be partly attributed to the lack of bank transparency (see Fischer, 1999; Nier, 2005; Tadesse, 2006). Baumann and Nier (2004) show that banks with a higher amount of disclosure regarding their risk level tend to take lower risk. Nier (2005) also finds that more transparent banks are less at risk of experiencing financial problems and that their stock prices are less volatile ${ }^{2}$. Nier and Baumann (2006) show that greater disclosure and transparency lead to stronger market discipline and hence to lower risk-taking. They also show that the effect of disclosure diminishes when there is evidence of a high degree of government support in the case of bank failure.

Nevertheless, a higher amount of disclosure and hence transparency might also be counterproductive. First, as a bank discloses more information, it has to bear an increasing cost of production and dissemination of such information. Furthermore, by releasing more information, competitors could extract and exploit key information to take advantages (Hyytinen and Takalo, 2003). Regarding this, Tadesse (2006) argues that bank transparency may be linked to banking system stability in various ways. In the "disclosure-fragility' view, it is believed that a negligible problem affecting a given bank may destroy the trust of all depositors as this problem is revealed to the public. This approach departs from the assumption that a bank's nature of business is highly dependent on public trust. With this regard, a higher level of disclosure could endanger banking stability when problems in specific banks trigger a projection of general problems in the banking system as a whole generating bank runs and panics (Gilbert and Vaugan, 1998; Kaufman and Scott, 2003; Gorton \& Huang, 2006). Further disclosure could hence wipe out investors' confidence and lead to the failure of both

\footnotetext{
${ }^{2}$ Nier (2005) uses large changes in banks' stock prices as a market indicator of banking problems. He argues that a bank is experiencing a severe problem when its stock price drops dramatically (i.e., stock returns of $-50 \%$ or worse) and hence the change not only indicates the extent to which risk has materialized, but also incorporates the effect of any resulting responses in credit spreads of the bank.
} 
strong and weak banks rather than providing a better monitoring vehicle (Tadesse, 2006).

Many works have documented the relationship between bank ownership structure and risk. In particular, Saunders et al. (1990) find a positive relationship between insider ownership and risk-taking for a sample of US banks during the 19781985 period. Using Saving and Loan associations (S\&Ls) data, Cebenoyan et al., (1995) show that a high level of managerial ownership is related to higher S\&Ls risktaking. Chen, Steiner and White (1998), however, find that managerial ownership is inversely related to depository institutions' risk. Their analysis further reveals that the relationship is non linear. Corporate control theory highlights that in the absence of adequate control by shareholders as well as the existence of information asymmetries managers could badly manage the bank and pursue riskier yet unprofitable investments for the growth purpose upon which their performance might be attributed. This problem is exacerbated when bank owners cannot effectively monitor bank managers and their performance. From the perspective of agency theory, this moral hazard behavior could be tempered by allowing managers to hold shares in order to align their interests with those of outside shareholders (Jensen and Meckling, 1976; Saunders et al., 1990; Allen and Cebenoyan, 1991). Empirically, Gorton and Rosen (1995) find that higher levels of managerial ownership in bank holding companies (BHCs) lead to lower credit risk.

However, since principal-agent relationships in banks involve many parties including creditors as well as other stakeholders and because bank assets are considered as opaque, higher managerial ownership might not necessarily lead to lower risk. The presence of the central bank as a lender of the last resort, for instance, could lead to higher risk-taking incentives. Hence, the effect of ownership on risk might not be always linear and positive. For example, evidence found by Anderson and Fraser (2000) shows that there is a positive link between insider ownership and bank risktaking. Other studies (Mork et al, 1988; Demsetz et al, 1997; Gorton and Rosen, 1995; Knopf and Dolde, 2006) find that such a relationship is not linear. They argue that a Ushaped insider ownership - risk taking relationship emerges because at very low level of ownership, almost all of the manager's wealth comes from predetermined compensations particularly salary leading to the persistence of agency problems. As their ownership increases, their interest will be aligned with those of outside 
shareholders but only above a certain threshold. Further above managers may become entrenched and are inclined to achieve their private agenda again. However, at that point, when a single party holds a large level of shares, another agency problem namely between large shareholders and small investors emerges. Large shareholders can divert funds for their own personal benefits in the form of special (hidden) dividends and preferential deals (Shleifer and Vishny, 1997; La Porta et al., 1998, Claessens \& Yurtoglu, 2013). They can impose some direct costs on other stakeholders, most notably the minority shareholders and employees.

Theory suggests that if ownership is widely dispersed among a large number of small shareholders the incentive to monitor the manager will be lower. This free rider problem inevitably induces more opportunistic behavior by managers. Studies by Demsetz and Lehn (1985), Prowse (1995), Faccio and Lang (2002), and Caprio et al. (2007) show that the banking sector particularly in developed markets is generally featured by a lower ownership concentration. In developing markets, such a situation, when coexisting with a lack of market discipline, might lead to a worse bank governance.

The existence of external shareholders such as institutional investors and block holders who have significant voting rights can also affect the level of risk-taking at a bank. Such agents are assumed to pay more attention and make more efforts to monitor bank risk-taking because of their large investment scale in shares and their expertise to do so compared to small investors (Shleifer and Vishny, 1986). These types of shareholders will promote shareholder-driven decisions including the careful control of the bank's riskiness. But they can also promote higher risk-taking if their wealth is sufficiently diversified. Wright et al. (1996) observe that whilst institutional ownership positively affect firms' risk-taking, block holding has no significant influence on bank risk. Interestingly, Knopf and Teall (1996) find a strong negative relationship between risk and outside ownership in the U.S. following the Financial Institutions Reform, Recovery and Enforcement Act of 1989 (FIRREA).

As another type of shareholding, government ownership is theoretically expected to encourage banks to maintain their financial soundness and to promote good governance. However, in many cases state-owned banks come under pressure to serve politically-related parties or are encouraged to take on more risk because they expect support (bail-out) in case on financial distress. Consistently, previous studies have 
found banks with government ownership to be more inclined towards higher risktaking strategies (Martinez-Peria, 2000; Barth et al., 2004; Berger et al., 2005; Iannotta et al., 2007).

Several studies have examined the relationship between disclosure and other variables. Using companies listed on the S\&P 500 index, Baek et al., (2009) observe that managerial ownership is negatively related to the level of disclosure. Such relationship is significant for firms with a low level of managerial ownership (i.e. $\leq 5 \%$ ) but not at higher level of managerial ownership (i.e. $\geq 5 \%$ ) where managers tend to make a very limited and selective disclosure. Nevertheless, a study by Eng and Mak (2003) finds that lower managerial ownership and significant government ownership are linked with increased disclosure.

From an agency theory perspective, the principal should monitor the agent in order to prevent potential expropriation by the latter. Hence, institutional investors that have a large amount of shares in a bank should exert strong monitoring efforts. With their strong position and expertise, institutional investors can impose a disclosure requirement as a low-cost mechanism to monitor the bank manager's performance. Healy et al (1999) observe a positive relationship between disclosure quality, measured by AIMR rating ${ }^{3}$, and institutional ownership. Similarly, Bushee and Noe (2000) find that institutions with a large amount of ownership have several reasons to require higher quality of disclosure as a way to offset monitoring costs. At a first stage, as disclosure increases, the impact on the bank's stock price volatility is negative due to lower information asymmetry. They conclude that the smoother behavior of stock prices decreases the cost of capital. At a second stage, a better disclosure could provide profitable trading opportunities that attract institutional investors (Baumann and Nier, 2004). Eventually, investors with low access to private information may have to rely more on public information (see Healy and Palepu, 2001; Hassan \& Marston, 2010). Therefore, ceteris paribus, they might also prefer the bank with higher level of disclosure.

\footnotetext{
${ }^{3}$ AIMR rating is a disclosure survey conducted by the Association for Investment Management and Research (AIMR). This measure of disclosure reflects the evaluations (rating) of leading financial analysts for companies' aggregate disclosure (mandatory and voluntary disclosure) within three categories: annual published and other required information, quarterly and other published but not required information, and other aspects of disclosure such as investor and analyst relations. The final disclosure score is calculated as a weighted average of those three categories.
} 
The discussions above suggest that the effect of disclosure on bank risk is debatable and seemingly conflicting. Agency theory argues that an adequate level of disclosure is of importance for outside investors as well as inside shareholders to monitor the bank manager's risk-taking behavior. As the nature of banking business is more opaque compared to other industries, banks should be subject to stringent disclosure requirement. In line with this, the disclosure-stability theory predicts that a greater level of disclosure and subsequent transparency will allow for stronger market discipline through better asset allocation and lower asymmetric information among market participants. In the presence of better disclosure, investors can judge the bank's performance more accurately and less risky banks will enjoy a lower cost of funding while riskier banks will suffer from higher cost and higher probability of default. Hence, better disclosure will lead banks to pursue lower risk strategies on average. On the other hand, a higher level of disclosure could be a catalyst for minor and specific bank problems to turn into widely spread rumors depleting investors' confidence and triggering a bank run. As such the relationship between disclosure and bank risk-taking and default risk can be either positive or negative. Also, it has been argued that disclosure is strongly related to corporate governance characteristics and in particular to ownership characteristics while the latter also affect risk-taking behavior. Hence, we predict that the effect of disclosure on risk will closely depend on the ownership structure of banks.

\section{Data and Empirical Specifications}

We retrieve data from Bankscope for publicly-listed commercial banks in 11 Asian countries ${ }^{4}$ over the $2004-2010$ period. For the countries we consider, Bankscope has reported financial/accounting information for 216 commercial banks which provides us with 1728 bank-year observations. When some observations are missing, we look into annual reports which we download from the banks' websites or other sources. In some countries such as Vietnam, banks do not provide up-to-date reports on their websites in which case our sample is relatively limited. We delete banks with less than four consecutive years of observations ${ }^{5}$. We exclude outliers by eliminating

\footnotetext{
${ }^{4}$ China, India, Indonesia, Japan, South Korea, Malaysia, Philippines, Singapore, Taiwan, Thailand, and Vietnam.

${ }^{5}$ This condition allows us to accurately compute the standard deviations of some variables to estimate risk measures.
} 
the extreme observations (1\% lowest and 1\% highest values) and check the statistical properties of the considered variables by conducting mean tests and distribution tests for all the variables. Most of our country level variables (i.e. interest rate, inflation, growth) come from WDI (World Development Index) by the World Bank. The deposit insurance coverage data are retrieved from Demirgüç-Kunt et al., (2005) but we also rely on the information provided by the central bank or the deposit insurance institution in each country to match the data with our sample period. We eventually end up with 209 banks and approximately 1451 bank-year observations to perform our empirical investigation.

\subsection{Risk proxies}

We use three measures as a proxy for risk which is our dependent variable. First, as many previous studies, we use the Z-score as a proxy for default risk (Boyd and Graham, 1988; Goyeau and Tarazi, 1992; Lepetit et al., 2008; Barry et al., 2011). This score is defined as (ROA + EA) / SDROA, where ROA is the bank's return on assets, EA is the ratio of equity to total assets, and SDROA is the rolling standard deviation of ROA based on observations in year $t, t-1$ and $t$-2 (Agoraki et al. 2011). We also split the Z-score into its two components Z-score 1 defined as ROA divided by SDROA and Z-score 2 which is EA divided by SDROA. Z-score 1 is expected to measure asset risk and Z-score 2 leverage risk. Second, we consider as a proxy of risktaking, the ratio of non-performing loans-to-bank capital (NPL-to-CAP) as in Angkinand and Wihlborg, (2010). Accordingly, we use SDROA as a measure of income volatility. As an alternative proxy, we also use the standard deviation of the return on average equity (SDROE) ${ }^{6}$.

\subsection{Disclosure, ownership and other variables}

The main independent variable in this study is the disclosure index (DI). Previous studies on disclosure generally conclude that disclosure can be analyzed and measured by two main approaches (Hassan and Marston, 2010); indirect approach (e.g. perception of financial analysts/investors on banks' disclosure practices) and direct approach (e.g. content analysis, disclosure of good/bad news, and disclosure index). Our disclosure index in this study is based on an extensive list of items that could be disclosed in bank reports (annual report, financial statements, regulatory report,

\footnotetext{
${ }^{6}$ We define average equity at time $t$ as (outstanding equity at time $t+$ outstanding equity at time $\left.t-1\right) / 2$.
} 
prospectus et cetera). Each item can either refer to a mandatory or a voluntary item. More specifically, we consider a Disclosure Index (DI) in the steps of Baumann and Nier (2004), and Nier (2005) which is based on the information provided by 17 items referring - in the Bankscope database - to bank assets, liabilities, memo lines, capital, and also off-balance sheet items (see Appendix $\mathrm{C}$ for the list of the 17 accounting items). This index represents whether a bank discloses one or more sources of risk (e.g., interest rate risk, credit risk, liquidity risk, market risk). Each item is assigned a value of 1 if an expected financial item is reported and 0 otherwise with the exception of the index for securities by type and the capital index for which we assign the values of 2 and 3 respectively to obtain a total maximum value of 21 . The composite index is then estimated by dividing the obtained value by 21 and hence the composite index ranges from 0 when none of the items are reported to $1(100 \%)$ when all the items are reported. Regarding ownership, we consider various characteristics as discussed above. First, following Morck et al., (1988), Gorton and Rosen (1995), and Demsetz et al., (1997) we use insider ownership (Insider) which is defined as the percentage of stocks held by officers or directors within a bank. Second, we account for institutional ownership (Inst) that represents the percentage of shares held by institutional investors. Third, we measure block shareholders (Block) as the sum of the shares owned by individuals who own 5 percent or more of equity divided by total outstanding shares of the bank. Fourth, we measure ownership concentration (HHI) using a HerfindahlHirschman Index with 100 representing the most concentrated ownership and 0 as the most dispersed (see Appendix B for the formula). Fifth, we measure government or state ownership (Gown) by the percentage of shares held by the government.

In our regression framework we consider a set of firm and country-level control variables. On the bank level, the franchise value is likely to affect bank risk-taking. Demsetz et al., (1997) and Laeven and Levine (2009) argue that banks with higher franchise value are likely to take less risk since higher franchise values imply higher bankruptcy costs. To capture this effect, we use the ratio of market-to-book value of equity (PBV) which is measured by the ratio of market value of equity to its book value. We expect a negative coefficient for this variable. Next, we use the tier 1 capital ratio (Tier1) as a measure of bank capitalization or leverage. Banks with higher level of capital are able to more easily sustain loss events and hence avoid failure. Bank capital might also determine the level of risk that banks might be willing to take. As 
such, this ratio is expected to capture the bank's degree of risk aversion. We also consider the effect of size on bank risk. As size increases, banks may benefit from better portfolio diversification benefits leading to a negative relationship with risk. Also, as bank size increases, the disclosure requirement will be higher improving stakeholders' ability to monitor and prevent banks from excessive risk-taking. On the other hand, by increasing its size, a bank could benefit from To-Big-To-Fail (TBTF) safety net subsidies (De Nicolo, 2000). In this regard, there could be a positive relationship between bank size and risk. In this study, size is measured by the natural logarithm of book value of total assets (Size).

At the country level, we control for the GDP growth, real interest rates, inflation rates, and deposit insurance coverage. GDP Growth (Growth) is measured as the real GDP growth rate (Lee, 2009; Angkinand and Wihlborg, 2010). Interest rates could affect banks' cost of funds as well as borrowers' behavior. An increase in the interest rate is often associated with higher problem loans and default rates that eventually affect the riskiness of banks themselves. We use the real interest rate (Interest) (Lee, 2009; Angkinand and Wihlborg, 2010; Forssbæck, 2011). Next, the inflation rate (Inflation) will determine how banks behave and will hence impact both their assets and liabilities (Lee, 2009; Angkinand and Wihlborg, 2010; Forssbæck, 2011). We also consider deposit insurance as a control variable. Better covered depositors will likely have a weaker incentive to monitor the bank to prevent it from pursuing riskier activities (Demsetz et al, 1997). Furthermore, explicit deposit insurance is often considered as creating higher moral hazard incentives leading to higher financial fragility and increasing the likelihood of bank crises (Demirgüç-Kunt and Detragiache, 2002). Deposit insurance (Covdep) is measured by $\ln (1+$ coverage of deposit insurance) where coverage of deposit insurance is the ratio of the explicit coverage limit per deposit account to the average deposit per capita (Demirguç-Kunt et al., 2005; Angkinand and Wihlborg, 2010).

These variables are used to estimate a panel model to capture the impact on risk of disclosure for different types of ownerships, as follows:

$\operatorname{Risk}_{i, t}=\beta_{0}+\beta_{1} \mathrm{DI}_{i, t}+\sum_{\mathrm{j}=2}^{6} \beta_{\mathrm{j}} \mathrm{Own}_{i, t}+\sum_{\mathrm{j}=7}^{11} \beta_{\mathrm{j}} \mathrm{DIxOwn}_{i, t}+\sum_{\mathrm{j}=12}^{\mathrm{n}} \beta_{\mathrm{j}} \operatorname{Controls}_{i, t}+$ Year control $+\varepsilon_{i, t}(1)$

where, Risk is either the Z-score, Z-score 1, Z-score 2, NPL-to-Cap, SDROA, or SDROE. DI is the disclosure index. Own is either insider ownership (Insider), 
institutional ownership (Inst), government ownership (Gown), blockholder ownership (Block), or HHI. DIxOwn stands for the interaction terms, defined as the disclosure index times each ownership variable to capture the relationship between disclosure and risk for different ownership characteristics and levels. Controls is a vector of control variables consisting of the price-to-book ratio (PBV), total assets (Size), the tier-1 capital ratio (Capital), GDP growth (Growth), the real interest rate (Interest), the inflation rate (Inflation), deposit insurance coverage (Covdep), and also year control. Appendix B gives detailed descriptions of these variables.

\section{Empirical Results}

\subsection{Univariate Analysis}

Table 1 presents the descriptive statistics for the whole sample of 209 banks and Table 2 reports the information country by country. Overall, the banks in our sample exhibit sufficient heterogeneity to conduct an empirical investigation. Banks have on average a Z-score of 81.6 with banks in Malaysia reaching on average the highest value followed by Singapore, Philippines, Japan, Thailand, India, China, Taiwan, Indonesia, South Korea, and Vietnam. In terms of Z-score 1, Malaysian banks also present the highest score (23.39), but now followed by India (10.17), and Thailand (9.37). The average value for all countries is 6.4. Similar to Z-score, Malaysia, Singapore, and Japan are countries with the highest Z-score 1 . The average value for all countries is approximately 74.9 .

\section{[INSERT TABLE 1 HERE]}

Interestingly, in terms of NPL-to-Cap, banks in South Korea exhibit the lowest value followed by Singapore, Taiwan, India, Malaysia, Indonesia, Japan, China, and Philippines. Having experiencing the hardest hit during the 1997 financial crisis, Thailand still seems to suffer from higher levels of the NPL-to-Cap ratio (1.16) compared to others (the full sample mean is equal to 0.69). Turning to other risk measures, the standard deviations of ROA (SDROA) are found to be relatively high, on average, in some countries particularly in Indonesia, Taiwan, and Thailand. Accordingly, SDROE shows similar patterns banks in Taiwan, Thailand, and Indonesia exhibiting the highest values. 
Table 2 shows that the average disclosure index is $0.65(65.09 \%)$ with higher values for Thailand, Singapore, China, South Korea, Malaysia, Philippines, and Japan (see also Table 3 Panel A). Note that this index only reflects the amount of items disclosed and does not necessarily represent the quality or reliability of disclosure. Hence, a higher index should be interpreted as banks providing more information upon which outside investors can make a better assessment regarding risk and/or performance.

\section{[INSERT TABLE 2 HERE]}

The average of the disclosure index increases from around $0.59(58.53 \%)$ in 2004 to $0.65(64.83 \%)$ in 2010 suggesting that Asian banks now disclose more financial items than in previous years (Table 3 Panel B).

\section{[INSERT TABLE 3 HERE]}

As expected, insider ownership (Iown) reported in Table 1 is generally not as pervasive as those in other industries. This could be attributed to the fact that the banking industry is subject to tighter regulation that makes it uneasy for individuals to hold a larger amount of shares. Hence, we can see that insider ownership only reaches the average of $0.65 \%$. We also note that insider ownership in most banks is very low although for a few banks, it can reach $49.67 \%$ in South Korea and India. We observe a very small percentage in Japan, Malaysia, Taiwan, China, Thailand, and Indonesia. On the other hand, the average insider ownership for banks in Vietnam, Philippines, India, Singapore and South Korea is relatively higher than the full sample mean $(0.65 \%)$.

We consider institutional ownership (Inst) as the percentage of shares held by any type of institutional investors. The average of Institutional ownership is $51.05 \%$, suggesting that banks in Asia are mainly controlled by institutional investors with lower levels in Japan (24.95\%). Government ownership is higher in India, Indonesia, China, Malaysia and South Korea. Indonesia, India, China, Philippines and South Korea exhibit considerable levels of block shareholders with more than $50 \%$ on average (higher than the sample mean of $40 \%$ ).

Ownership in Indonesian banks is the most concentrated one with a HHI index of around $40 \%$ followed by India, China, South Korea and Thailand. This is consistent 
with Claessens et al., (2000) who find that the ownership in Asian countries is concentrated among few investors and that concentration is lower in countries with higher level of economic development. Consistently, they find that Indonesia and Thailand are among the countries with the largest concentration of ownership. Overall, the average concentration proxy is equal to $19.28 \%$ for the full sample. Other control variables, both at the bank and country level, are also presented in Table 1.

Table 4 presents the correlations between the variables used in our study. As expected, the disclosure index (DI) is positively correlated with Z-score, Z-score 1, and Z-score2 and negatively with SDROA, and SDROE. In other words, a higher level of disclosure is apparently associated with a lower level of risk although the correlation coefficients are relatively low.

[INSERT TABLE 4 AROUND HERE]

The correlations between ownership variables (Insider, Inst, Gown, Block, $\mathrm{HHI}$ ) and the Z-score are all negative and those between the ownership variables and the other risk proxies generally positive. These simple correlation measures suggest that risk is both associated with disclosure and ownership structure as reported in previous literature. The correlation matrix shows that many of our ownership variables are strongly correlated. Thus to deal with collinearity issues we introduce the ownership variables one by one in the regressions.

We now turn to our regression analysis which enables to capture the effect of disclosure under different ownership profiles. Our aim is to investigate whether disclosing more information will allow banks to be better monitored and specifically whether the incentives of any large or majority shareholders to push the banks toward more risky investments will be restricted.

\subsection{Baseline regressions}

Previous studies highlight that empirical governance research often suffers from serious endogeneity concerns (see Wintoki et al, 2012; Andres \& Vallelado, 2008). In our case, our main variable of interest, disclosure, is presumably endogenous. The demand for more disclosure, for instance, may be driven by factors such as the degree of asymmetric information between bank managers (insider) and outside investors or between minority versus majority shareholders (i.e. ownership characteristics) or the 
disclosure requirement in each country (e.g. voluntary versus mandatory). In such a case, panel regression within estimators, for instance, would be inconsistent.

To deal with this potential problem, we use the instrument variable (IV) model for our panel data as proposed by Schaffer $(2010)^{7}$. We face the issue of which variable can be used as the instrument i.e. highly correlated with the variables of interest but uncorrelated with the error term. We consider regulatory quality and the natural logarithm of the bank's age as the instruments by checking their validity with the Hansen test. Cheng and Courtenay (2006) argue that the level of voluntary disclosure is related to the regulatory environment. Ciancanelli and Reyes (2001) argue that regulation might be considered as an external governance force that acts at the banking industry level as a whole and at the level of individual banks. One can also argue that disclosure is also related to investors' legal protection; the better the legal protection, the better the quality and the quantity of information flow to investors. For this purpose, we use the regulatory quality index and government effectiveness index, a part of The Worldwide Governance Indicator developed by Kaufmann et al., (2010). This indicator captures the perceptions of the ability of the country to formulate and implement sound policies and regulations that permit and promote private sector development. The age (in natural logarithm) of the bank, by construction, is exogenous. Table 5 reports the output of the baseline regressions. In each panel, we run a regression with the disclosure index (DI) and ownership variables

First of all, in each of the first stage regressions, the F-test of the null hypothesis that the exogenous variables do not explain the endogenous regressors (DI) is rejected at the one percent significance level. In other words, disclosure is actually endogenous and affected by other variables as confirmed by the endogeneity tests (see the last rows Table 5). We also find that the F-statistics on the excluded instruments in the first stage regressions are above $10^{8}$, suggesting that our instruments are sufficiently strong. In Table 5, we report the Hansen J-statistic of the null hypothesis that all instruments are uncorrelated with the error term indicating that our instruments in all models are valid. Our results reveal that disclosure is not exogenous and hence the IV model is more efficient except for the NPL-to-Cap regression.

\footnotetext{
${ }^{7}$ The instrument variable models are obtained using the Schaffer 'xtivreg2' module (Schaffer, 2010) in stata

${ }^{8}$ As a rule of thumb, F-statistics above 10 suggest that the instruments are sufficiently strong (Stock, Wright and Yogo, 2002). To conserve the space, the results are available upon request.
} 


\section{[INSERT TABLE 5 AROUND HERE]}

With regard to the disclosure index (DI), the coefficients of DI are generally consistent with the disclosure-stability view. As expected, the disclosure variable is positively related to default risk and negatively related to income volatility in accordance with previous work (Cordella and Yeyati (1998), Fischer (1999), and Nier and Baumann (2006)). Better disclosure is also associated with lower bank default risk. Banks with better disclosure also engage in less risky investments as captured by the volatility of their returns.

The coefficient of insider ownership (Iown) is only significant for Z-score 1 models. Also, the coefficient of institutional ownership (Inst) is never significant.

However, our results report that government ownership is associated with higher default risk and higher income volatility. Claessens et al., (2000) argue that in Asia, families or conglomerates commonly hold the majority of corporate shares while the states hold less. However, in our sample state ownership is also prevalent and our results show that government ownership (Gown) encourages banks to take more risk. In such banks, managers might have greater incentives to follow their own interests, favor government enterprises or to be more inclined towards relationship lending. Our result is in line with previous studies (Barth et al., 2004; Berger et al., 2005; Iannota et al., 2007; Angkinand and Wihlborg, 2010).

Block ownership is significantly positively related to default risk (higher Zscores indicate lower default risk) and income volatility but concentration (HHI) has no impact on risk. The coefficients of PBV (the price-to-book ratio as a proxy of franchise value) and Size (bank size) are not significant.

As expected, the Tier-1 capital ratio positively affects Z-score and Z-score 2. Further, we find that higher economic growth (Growth) and larger deposit insurance coverage (Covdep) are related to higher default risk, income volatility, and credit risk, supporting the earlier work of Demirgüç-Kunt and Detragiache, (2002). A higher interest rate is associated with lower default risk as shown by the Z-score 1 models (significant at the 5\% for model (1) and (4) and at the 10\% for model (2) and (3)).

Lastly, we find limited evidence that inflation is linked to risk, considering that its coefficient is only significant at the $10 \%$ level for SDROE. 
In the next section, we first interact disclosure with ownership types to assess its impact for different ownership characteristics. We then decompose the disclosure index into sub-indices and examine their effect on risk.

\subsection{Interaction of Disclosure and Ownership}

Up to this stage we have examined the effect of disclosure as well as ownership on bank risk-taking incentives without considering their interplay. We now run augmented regressions with interaction terms between DI and various ownership variables. Our aim is to investigate whether the effect of disclosure is similar or not for different ownership structures. The results are reported in Table 6.

\section{[INSERT TABLE 6 AROUND HERE]}

As in our previous regressions the disclosure variable DI is significantly and negatively associated with default risk and income volatility. The results of the tests of the significance of the sum of the coefficients of the disclosure variable and each interaction term separately indicate that disclosure is effective in reducing risk (except for NPL-to-Cap) for all types of ownership arrangements (see the sums of coefficients and their significance tests in the last rows of Table 6). But the interaction terms, taken on their own, are also significantly different from zero implying that the effect of disclosure varies to some extent with differences in ownership characteristics.

Based on the sum of the coefficients of disclosure and the interaction term (DI+DIxOwnership) in each model, our results indicate that the impact of disclosure in is stronger in the presence of block holding (model 4), followed by institutional ownership (model 2), ownership concentration (model 5). The effect is the weakest in the presence government ownership (model 3) and insider ownership (model 1).

Our results are consistent with the conjecture that higher insider ownership will weaken the effect of disclosure because of the role played by managerial ownership in selecting which information should be disclosed or retained (Baek et al., 2009; Eng and Mak, 2003). Government ownership is also expected to lower the impact of disclosure on risk-taking if such banks are believed to be more easily bailed out in the event of financial distress.

Institutional investors, which are more sophisticated than small investors and hold a substantial portion of shares, have higher incentives to monitor which is also the 
case for the block holders. Their presence strengthens the impact of disclosure and provides higher discipline and more transparency for smaller investors.

On the whole our results show that the effect of disclosure on risk varies in the presence of different ownership profiles. Specifically, although better disclosure is associated with lower risk-taking the impact is weaker in the presence of government ownership and insider ownership and it is the strongest in the presence of block holders or institutional investors.

\subsection{Decomposing the disclosure index}

As discussed above, the disclosure index (DI) is a composite score gathered from 17 individual items on bank financial reports (Baumann and Nier, 2004; Nier, 2005). The regressions in the previous sections have enabled us to examine the effect of disclosure in its composite form. One could argue that a given component (sub index) might have a different impact compared to the other components. Note that the disclosure index we adopt in this study gives an equal weight to each component (sub index).

To take our investigation deeper, we decompose the disclosure index into its main groups by simply regrouping the items into disclosure on assets (i.e. loan (DILoan) and other earning assets (DIEA)), liability (i.e. deposits (DIDep) and other funding (DIFund)), memo lines (DIMemo) including contingent liabilities and Offbalance sheet items, and income statement (DIIS) as in the classification by the Bauman and Nier (2004) and Nier (2005) (see Appendix C). We expect such a decomposition to provide insights on which items/sub indices have a stronger impact on risk.

\section{[INSERT TABLE 7 AROUND HERE]}

Table 7 presents the regressions on the six disclosure sub indices (model 1 model 6) for each risk measure ${ }^{9}$. Disclosure on loans (DILoan), disclosure on other earning assets (DIEA), disclosure on deposits (DIDep), disclosure on bank's memo line (DIMemo), and disclosure on income statement (DIIS) have significant impacts on risk as better disclosure on these items are linked to lower income volatility (i.e. SDROA and SDROE) and default risk (i.e. Z-score, Z-score 1, and Z-score 2). These findings

\footnotetext{
${ }^{9}$ The results remain the same when we include the ownership variables.
} 
are consistent with the main results obtained with the composite index (DI). Nevertheless, we do not find any significant coefficients for the sub indices standing for credit risk. Furthermore, disclosure on funding sources (DIFund) is rarely significant or only at the ten percent level. DIFund is the disclosure sub index comprising disclosure on money market funding, long-term funding including bonds and subordinated debt. An extensive literature argues that because some types of funding such as subordinated debt are not insured a higher portion of such liabilities in the balance sheet will provide incentives to take on less risk. Otherwise banks will be charged higher rates or subject to higher withdrawal risk (Ellis and Flannery, 1992; Gropp and Vesala, 2004; Nier and Baumann, 2006). Hence, an increase in disclosure on DIFund is expected to temper risk-taking incentives. Its coefficient, however, is not significant for credit risk and income volatility.

\subsection{Robustness Checks}

In the previous sections, our models have accounted for various definitions of the dependent variable. This allows us to assess whether the effect of disclosure is robust. To check the consistency of the results, we also run standard panel regressions to control for time effects and unobservable heterogeneity ${ }^{10}$. The Hausman test concludes that fixed effect models are more consistent for all of our specifications ${ }^{11}$.

On the whole, the effect of disclosure remains the same (see Table A.1 for the baseline regressions). Hence, banks with higher disclosure have lower default risk and engage in less risky investments as captured by the volatility of their returns, confirming our previous findings.

Consistently with those of Table 5, the coefficients of insider ownership are only significant and positive for Z-score 1 . Similarly to the evidence provided in the baseline regression, we find that the coefficient of institutional ownership is never significant. State-owned banks are again found to take higher risk and to exhibit higher levels of default risk. Nevertheless, we do not obtain significant coefficients for Block, except in model (3) for Z-score 1. Again, the coefficient of HHI remains insignificant in line with the baseline model.

\footnotetext{
${ }^{10}$ The tests of redundant fixed effects-likelihood ratio suggest that this model (considering individual and time effects) is appropriate in this study.

${ }^{11}$ For brevity, the Hausman test outputs are not shown in the paper but are available from the authors upon request.
} 
We also run the fixed effect models by considering the interaction terms between disclosure and ownership variables (see Table A2). As a whole, our main findings remain the same except for SDROE which is no longer significant. .

Table A.3 reports the fixed effect regressions on the disclosure subindices (model 1 - model 6). Disclosure on loans (DILoan) and disclosure on other earning assets (DIEA) have significant impacts on risk; both are related to lower risk-taking and lower default risk in line with the disclosure-stability view. In contrast to the result in the IV models, we find that better disclosure on bank funding sources (DIFund) is generally linked with higher income volatility (SDROE) and default risk (Z-score and Zscore 1) whereas disclosure on deposits (DIDep) plays no significant role.

In addition, we further check the robustness of our results by considering alternative variables in the IV models ${ }^{12}$. We introduce ownership dummy variables for each type of ownership (i.e. d_Insiders, d_Inst, d_Gown, and d_Block). For instance, d_Insiders takes the value of one if the bank has insider ownership and zero otherwise. We hence replace the continuous variables with binary variables. Our main results remain the same.

\section{Conclusion and caveats}

The increasing complexity of bank businesses along with the global financial crisis of 2008 and various accounting scandals urge the need for better bank governance including disclosure requirements. More extensive and better disclosure is expected not only to reduce information asymmetries but also to mitigate agency problems particularly between bank managers and outside stakeholders, allowing outside investors as well as supervisory bodies to better monitor financial institutions. In some cases, higher disclosure is desirable because it can lead to lower cost of capital. The Basel accord, accordingly, encourages more disclosure to prevent banks from excessive risk-taking.

This study examines the link between bank risk and the level of disclosure. We consider a sample of 209 commercial banks in Asia during the 2004-2010 period. Our findings show that higher disclosure scores are associated with lower default risk and lower bank income volatility. Also, the effect of disclosure on risk varies depending on the bank's ownership structure. As a whole, better disclosure is associated with lower

\footnotetext{
${ }^{12}$ For the sake of brevity, we do not report the obtained results but they are available on request.
} 
risk but its impact is stronger in the presence of block holders and also institutional investors as shareholders than the presence of the government or insiders. We decompose the disclosure index into six subindices and find that disclosure on certain items of the balance sheet (loans, other earning assets, deposits,), memo lines (loan loss reserves, capital ratio, contingent liabilities, \& Off-balance sheetand the income statement (non-interest income and loan loss provisions) plays an important role in mitigating risk especially regarding default risk and volatility of bank returns. Compared to others, the disclosure on other-funding items (money market funding and long-term funding), however, plays a much less significant role in attenuating risk.

Our results support policies aiming to enhance transparency, disclosure requirements, and market discipline in the banking industry. But we also show that the benefits of disclosure are dependent on banks' internal governance mechanisms and more specifically their ownership structure. Since the banking sector in Asia is characterized by concentrated ownership and often inadequate corporate governance (Claessens et al., 2000; Claessens \& Yurtoglu, 2013), our results shed light on the importance of carefully emphasising disclosure but also good governance practices in such a banking environment. Specifically, disclosure might be useful to mitigate possible expropriation/tunnelling activities by controlling shareholders. Nevertheless, drawing any lesson on how better disclosure will impact bank risk is too early since corporate governance initiatives and reforms are still ongoing in Asian banking sectors. 


\section{References}

Agrawal, A. and Mandelker, G.N., 1987. Managerial incentives and corporate investment and financing decisions. Journal of Finance, XLII.4.

Agoraki, M.K., Delis, M. D., and Pasiouras, F., 2009. Regulations, competition and bank risk-taking in transition countries. Journal of Financial Stability 7(1), 38-48.

Ali, M. J., Ahmed, K., \& Henry, D., 2004. Disclosure compliance with national accounting standards by listed companies in South Asia. Accounting and Business Research 34(3), 183-199.

Allen, L., and Cebenoyan, A.S., 1991. Bank acquisitions and ownership structure: Theory and evidence. Journal of Banking and Finance 15, 425-48.

Anderson, R.C., Fraser, D.R., 2000. Corporate control, bank risk-taking, and the health of the banking industry. Journal of Banking and Finance 24, 1383-1398.

Angkinand, Apanard \& Wihlborg, Clas, 2010. Deposit insurance coverage, ownership, and banks' risk-taking in emerging markets. Journal of International Money and Finance. Elsevier, vol. 29(2), 252-274

Baek, H.Y, Johnson, D.R., Kim, J.W, 2009. Managerial ownership, corporate governance, and voluntary disclosure. Journal of Business \& Economic Studies $15(2), 44-61$.

Barry, T.A., Lepetit, L., Tarazi A., 2011. Ownership structure and risk in publicly held and privately owned banks. Journal of Banking and Finance 35, 1327-1340.

Barth, J. R., Caprio Jr., G., and Levine, R., 2004. Bank supervision and regulation: What works best? Journal of Financial Intermediation, 13 (2), 205-48.

Basel Committee on Banking Supervisions (BSBC), 2010. Basel III: International framework for liquidity risk measurement, standards and monitoring. www.bis.org/publ/bcbs188.htm

Basel Committee on Banking Supervisions, 2011: Basel III: A global regulatory framework for more resilient banks and banking systems. http://www.bis.org/publ/bcbs189.pdf

Bertay, A.C., Demirgüç-Kunt, A., Huizinga, H., 2013. Do we need big banks? Evidence on performance, strategy and market discipline. Journal of Financial Intermediation 22(4), 532-558. http://dx.doi.org/10.1016/j.jfi.2013.02.002. 
Baumann, Ursel and Erlend Nier, 2004. Disclosure, Volatility, and Transparency: An Empirical Investigation into the Value of Bank Disclosure, Federal Reserve Bank of New York Economic Policy Review. September 2004, 31-45.

Beck, T.H.L., Demirgüç-Kunt, A. and Levine, R., 2006. Bank concentration, competition, and crises: First results, Open Access publications from Tilburg University urn:nbn:nl:ui:12-3125498, Tilburg University.

Berger, A. N., Miller, N.H., Petersen, M. A., Rajan, G.R., and Stein, J.C., 2005. Does function follow organisational form? Evidence from the lending practices of large and small banks. Journal of Financial Economics 76, 237-269.

Boot, Arnoud W. A. \& Schmeits, Anjolein, 2000. Market discipline and incentive problems in conglomerate firms with applications to banking. Journal of Financial Intermediation 9(3), 240-273.

Bowen, R., Davis, A., \& Matsumoto, D., 2002, Do conference calls affect analysts' forecasts? The Accounting Review 77 (2), 285-316.

Boyd, J. H. and S. L. Graham, 1988. The profitability and risk effects of allowing bank holding companies to merge with other financial firms: A simulation study. Federal Reserve Bank of Minneapolis Quarterly Review 12, Spring, 3-20.

Botosan, C.A, 1997. Disclosure level and the cost of equity capital, The Accounting Review 72(3), 323-349.

Botosan, C.A., \& Plumlee, M.A., 2002. A re-examination of disclosure level and the cost of equity capital. Journal of Accounting Research 40, 21-40

Brewer, E. III, Saidenberg, M.R., 1996. Franchise value, ownership structure, and risk at saving institutions. Federal Reserve Bank of New York Research Paper \#9632.

Bushee, B. and Noe C., 2000. Corporate disclosure practices, institutional investors, and stock return volatility. Journal of Accounting Research 38, supplement, pp.171-202.

Caprio, G., Laeven, L., \& Levine, R., 2007, Governance and bank valuation. Journal of Financial Intermediation 16 (4), pages 584-617.

Caprio, G., Levine, R., 2002, Corporate governance in finance: Concepts and international observations. In: R. E. Litan, M. Pomerleano, \& V. Sundarajan (Eds.), Financial sector governance: The roles of the private and public sectors. Brookings Institution Press. 
Cebenoyan, A.S., Cooperman, E.S., and Register, C.A., 1999, Ownership structure, charter value, and risk-taking behavior for thrifts. Financial Management 28 (43$60)$.

Chen, C. R., Steiner, T.L., and Whyte, A.M., 1998. Risk-taking behavior and management ownership in depository institutions. Journal of Financial Research 21(1), 1-16.

Cheng, E.C.M., Courtenay, S.M., 2006. Board composition, regulatory regime and voluntary disclosure. The International Journal of Accounting 41, 262-289.

Chun, S.E., Nagano, M., Lee, M.H., 2011. Ownership structure and risk-taking behaviour: Evidence from Banks in Korea and Japan. Asian Economic Journal 25(2), 151-175.

Claessens, S., Djankov, S., Lang, L.H.P, 2000. The sparation of ownership and control in East Asian Corporations. Journal of Financial Economics 58, pp.81-112.

Claessens, S. and J. P. H. Fan. 2002. Corporate Governance in Asia: A Survey. International Review of Finance 3(2), 71-103.

Claessens, S., Yurtoglu, B.B., 2013. Corporate governance in emerging markets: A survey. Emerging Markets Review 15, 1-33.

Ciancanelli, P., \& Reyes-Gonzalez, J. A., 2000. Corporate governance in banking: A conceptual framework. Available at SSRN: http://ssrn.com/abstract=253714 or http://dx.doi.org/10.2139/ssrn.253714

Cordell, L. R., MacDonald, G. D., Wohar, M. E., 1993, Corporate ownership and the thrift crisis. Journal of Law and Economics 36, 719-756.

Cordella, T., Yeyati, E.L., 1998. Public disclosure and bank Failures. CEPR Discussion Paper No. 1886.

Ciancanelli, P., Reyes, J., 2001. Corporate Governance in Banking: A conceptual framework. Working Paper, SSRN. Available at: http://ssrn.com/abstract=253714

Esty, B. C., 1997. Organizational form and risk-taking in the savings and loan industry. Journal of Financial Economics 44, 25-44.

Francis, J.R., Khurana, I.K., \& Pereira, R. 2005. Disclosure incentives and effects on cost of capital around the word. The Accounting Review 80(4), 1125-1162.

Demsetz, Rebecca S., Saidenberg, Marc R. and Strahan, Philip E., 1997. Agency problems and risk-taking at banks, No 9709, Research Paper, Federal Reserve Bank of New York, http://econpapers.repec.org/RePEc:fip:fednrp:9709 
Demirgüç-Kunt, A., and Detragiache, E., 2002. Does deposit insurance increase banking system stability? An empirical investigation, Journal of Monetary Economics, 49, 1373-1406.

Demirgüç-Kunt, A., Karacaovali, B., Laeven, L., 2005. Deposit insurance around the World: A Comprehensive Database. World Bank Policy Research Working Paper, Washington, DC.

De Nicolo, Gianni. 2000. Size, charter value and risk in banking: an international perspective, International Finance Discussion Papers 689, Board of Governors of the Federal Reserve System (U.S.).

Diamond, D.W, 1984. Financial intermediation and delegated monitoring. Review of Economic Studies 51(3), 393-414.

Eng. L.L, and Mak, Y.T., 2003. Corporate governance and voluntary disclosure. Journal of Accounting and Public Policies 22(4), 325-345.

Faccio, Mara and Larry H.P. Lang. 2002, The ultimate ownership in Western European corporations, Journal of Financial Economics, 65:3, pp. 365-395.

Fama, Eugene F., 1980, Agency problems and the theory of the firm, The Journal of Political Economy, Vol. 88, No. 2., pp. 288-307.

Fama, Eugene F. and Jensen, Michael C., 1983, Separation of ownership and control. Journal of Law and Economics, Vol. 26, No. 2, pp. 301-325.

Fischer, S., 1999. Reforming the international financial system. The Economic Journal, $109,557-76$.

Forssbæck, J., 2011. Ownership structure, market discipline, and banks' risk-taking incentives under deposit insurance. Journal of Banking and Finance, 35 (10), 2666-2678.

Garcia-Marco, T., and Robles-Fernandez, M.D., 2008, Risk-taking behaviour and ownership in the banking industry: The Spanish evidence. Journal of Economics and Business 60, 332-354.

Gilbert, R.A. \& Vaughan, M.D, 1998, Does the publication of supervisory enforcement actions add to market discipline? Research in Financial Services: Public and Private Policy, 10, 259-80

Gorton, G, and Huang, L., 2006. Bank panics and the endogeneity of central banking. Journal of Monetary Economics 53(7), 1613-1629. 
Gorton, G. and Rosen, R., 1995, Corporate control, portfolio choice and the decline of banking. Journal of Finance, 50, 1377-420.

Goyeau, D., and Tarazi, A., 1992, Evaluation of risk of failure banking in Europe, Journal of Political Economy, 102 (3), 249-280.

Gorton, G., Rosen, R., 1995. Corporate control, portfolio choice, and the decline of banking. Journal of Banking and Finance 50, 1377-1420.

Hassan, O.A.G., Romilly, P., Giorgioni, G., \& Power, D, 2009, The value relevance of disclosure: Evidence from the emerging capital market of Egypt. The International Journal of Accounting, 44(1), 79-102.

Hassan, O., Marston, C., 2010. Disclosure measurement in the empirical accounting literature - a review article. Accountancy Discussion Papers 1004, Accountancy Research Group, Heriot Watt University

Healy, P. M., \& Palepu, K. G., 1993, The effect of firms' financial disclosure strategies on stock prices. Accounting Horizons, 7 (1), 1-11.

Healy, P. M., \& Palepu, K. G., 2001. Information asymmetry, corporate disclosure, and the capital markets: a review of the empirical disclosure literature. Journal of Accounting and Economics, 31 (1-3), 405-440.

Healy, P. M., Hutton, A. P and Palepu K. G., 1999, Stock performance and intermediation changes surrounding increases in disclosure, Contemporary Accounting Research, 16, 485-520.

Hyytinen, A., Takalo, T., 2002. Enhancing bank transparency: A re-assessment. European Finance Review 6 (3), 429-445. doi:10.1023/A:1022037025942

Iannotta, G., Nocera, G., Sironi, A., 2007. Ownership structure, risk and performance in the European banking industry. Journal of Banking and Finance 31, 2127 2149 .

Jensen, Michael and Meckling, W., 1976. Theory of the firm: Managerial behavior, agency costs and ownership structure, Journal of Financial Economics, 3, 305360 .

Jensen, Michael C., 1986, Agency cost of free cash flow, corporate finance, and takeovers, American Economic Review, 7, 323-329.

Karels, G. V., \& McClatchey, C., 1999, Deposit insurance and risk-taking behavior in the credit union industry. Journal of Banking and Finance, 23, 105-134. 
Kaufmann, D.., Kraay, A., Mastruzzi, M., 2010. The Worldwide Governance Indicator: A summary of methodology, data, ad analytical issues. World Bank Policy Research Working Paper No. 5430.

Kaufman, G.G., Scott, K.E., 2003. What is systemic risk and do bank regulators retard or contribute to it? Independent Rev. VII, 372-391.

King, R. G. and Levine, R., 1993a. Finance and growth: Schumpeter might be right, Quarterly Journal of Economics, 108, 717-37.

King, R.G and Levine, R., 1993b. Finance, entrepreneurship and growth: Theory and evidence, Journal of Monetary Economics, 32, 513-42.

Knopf, J. D. and J. L. Teall, 1996. Risk-taking behavior in the U.S. thrift industry: Ownership structure and regulatory changes, Journal of Banking and Finance, 20: 1329-1350.

Laeven, Luc, and Levine, Ross, 2009, Bank governance, regulation and risk-taking, Journal of Financial Economics, 93, 259-275.

La Porta, R., Lopez-de-Silanes, F., Shleifer, A., 1999. Corporate ownership around the world. Journal of Finance 54, 471-517.

La Porta, R., Lopez-de-Silanes, F., Shleifer, A., Vishny, R.W., 1998. Law and Finance. Journal of Political Economy 106 (6), 1113-1155.

Lee, Seok W., 2002, Insider ownership and risk-taking behaviour at bank holding companies, Journal of Business Finance and Accounting, 29 (7), 989 - 1005.

Lee S-J, D. Mayers, and C.W. Smith, Jr ,1997. Guaranty funds and risk-taking evidence from the insurance industry, Journal of Financial Economics, 44, 3-24.

Lepetit, L., Nys, E., Rous, P., Tarazi, A., 2008. Bank income structure and risk: an empirical analysis of European banks. Journal of Banking and Finance 32, 14521467.

Levine, Ross, 2003. The corporate governance of banks: A concise discussion of concepts and evidence, Working Paper of Global Corporate Governance Forum, Washington DC.

Levine, Ross, 2004. The Corporate Governance of Banks - a concise discussion of concepts and evidence. Policy Research Working Paper Series 3404, The World Bank.

Maria Soledad Martinez Peria, 2002, The impact of banking crises on money demand and price stability," IMF Staff Papers, Palgrave Macmillan, 49(3), 1. 
Morck, R., A. Shleifer and R. Vishny 1988, Management ownership and market valuation: An empirical analysis', Journal of Financial Economics, Vol. 20, pp. $293-316$.

Morgan, D. 2002. Rating banks: Risk and uncertainty in an opaque industry. The American Economic Review 92 (4), 874-888.

Nier, Erlend W., 2005. Bank stability and transparency. Journal of Financial Stability $1,342-354$

Nier, E., and Baumann, U., 2006. Market discipline, disclosure and moral hazard in banking. Journal of Financial Intermediation, 15, 332-361.

Prowse, S., 1995. Corporate governance in an international perspective: a Survey of corporate control mechanisms among large firms in the US, UK, Japan and Germany. Financial Markets, Institutions and Instruments, 4, 1-63.

Roodman, D. (2006). How to do xtabond2: An introduction to "difference" and "system" GMM in Stata. Working paper, Center for Global Development, Washington.

Saunders, A., Strock, E., \& Travlos, N. G., 1990, Ownership structure, deregulation, and bank risk-taking. Journal of Finance, 45 (2), 643-654.

Schaffer, M.E., 2010. xtivreg2: Stata module to perform extended IV/2SLS, GMM and $\mathrm{AC} / \mathrm{HAC}$, LIML and k-class regression for panel data models. http://ideas.repec.org/c/boc/bocode/s456501.html

Shleifer, A., and R. Vishny, 1986, Large shareholders and corporate control. The Journal of Polictical Economy, 94, 461-488.

Shleifer, Andrei and Robert W. Vishny, 1997, A Survey of Corporate Governance, Journal of Finance 52(2), 737-783.

Stock, J.H., Wright, J.H., Yogo, M., 2002. A survey of weak instruments and weak identification in General Method of Moments. Journal of Business and Economic Statistics 20(4), 518-29.

Tadesse, S., 2006. The economic value of regulated disclosure: Evidence from the banking sector. Journal of Accounting and Public Policy 25, 32-70

Watson A., Shrives P., Marston C., 2002., Voluntary disclosure of accounting ratios in the UK. British Accounting Review 34: 289-313 
Wilson, J.O.S, Casu, B., Girardone, C., and Molyneux, P., 2010, Emerging theme in banking: Recent literature and directions for future research. The British Accounting Review 42, 153-169

Wooldridge, J.M. 2002. Econometric Analysis of Cross Section and Panel Data. Cambridge, MA: MIT Press.

Wright, P., Ferris, S.P., Sarin, A., and Awasthi, V., 1996, Impact of corporate insider, blockholder, and institutional equity ownership on firm risk-taking, Academy of Management Journal , 39 (2), 441-463 
Table 1. Summary statistics: bank risk, disclosure and other variables for the 2004-2010 period

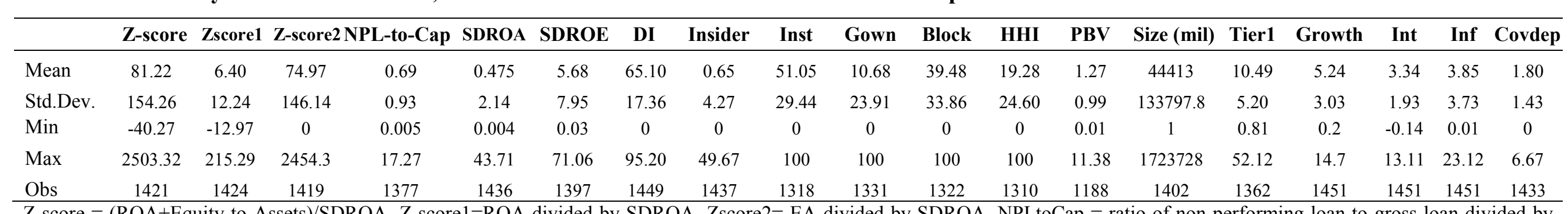

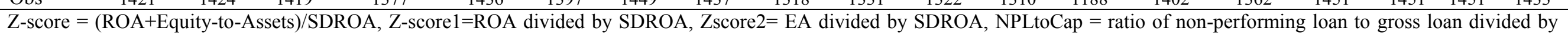

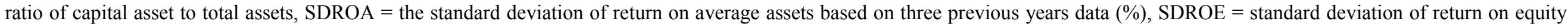

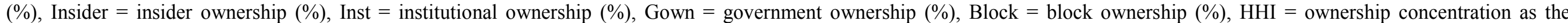

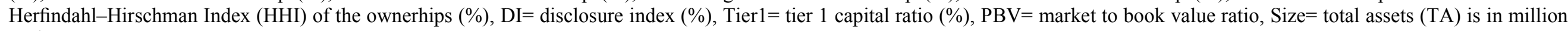
US\$, Covdep $=\ln (1+$ coverage of insurance deposit $)$, Growth $=$ growth of gross domestic product, Interest $=$ real interest rate $\mathrm{p} . \mathrm{a}(\%)$, Inflation $=$ inflation rate $\mathrm{p} . \mathrm{a}(\%)$. 
Table 2. Bank risk, disclosure and other variables on average over the 2004-2010 period by country

\begin{tabular}{|c|c|c|c|c|c|c|c|c|c|c|c|c|c|c|c|c|c|c|c|}
\hline Country & Z-score & Z-score1 & Zscore2 & NPL-to-Cap & SDROA & SDROE & DI & Insider & Inst & Gown & Block & HHI & PBV & Size (mil) & Tier1 & Growth & Int & Inf & Covdep \\
\hline China & 61.27 & 8.95 & 51.41 & 0.92 & 0.17 & 4.92 & 78.27 & 0.00 & 64.04 & 13.62 & 53.40 & 21.48 & 1.99 & 397948.9 & 8.91 & 11.03 & 2.25 & 3.38 & 0.00 \\
\hline Indonesia & 55.94 & 6.08 & 49.82 & 0.61 & 1.25 & 5.44 & 56.93 & 0.32 & 74.81 & 14.44 & 77.53 & 40.66 & 1.83 & 5972.502 & 14.65 & 5.60 & 3.74 & 8.36 & 4.59 \\
\hline Japan & 96.40 & 4.12 & 92.27 & 0.81 & 0.32 & 5.58 & 67.61 & 0.04 & 24.95 & 0.00 & 8.73 & 3.24 & 1.02 & 33355.31 & 9.13 & 2.63 & 2.69 & 0.67 & 1.07 \\
\hline S-Korea & 51.60 & 4.72 & 46.89 & 0.15 & 0.30 & 5.05 & 76.30 & 3.57 & 66.55 & 12.38 & 53.88 & 25.80 & 1.29 & 41210.48 & 8.83 & 3.92 & 4.59 & 3.08 & 1.29 \\
\hline Malaysia & 156.01 & 23.39 & 132.61 & 0.42 & 0.14 & 2.25 & 74.60 & 0.07 & 69.11 & 15.01 & 51.85 & 19.46 & 2.21 & 46513.2 & 11.90 & 5.44 & 3.16 & 2.55 & 2.53 \\
\hline Philippines & 96.91 & 6.11 & 90.71 & 0.99 & 0.48 & 2.85 & 70.11 & 2.57 & 67.87 & 1.91 & 64.91 & 20.87 & 1.09 & 5768.138 & 13.87 & 5.16 & 3.96 & 5.58 & 2.15 \\
\hline Singapore & 101.07 & 8.94 & 92.13 & 0.31 & 0.19 & 2.13 & 80.05 & 0.65 & 71.95 & 0.00 & 46.94 & 7.54 & 1.14 & 79015.47 & 13.77 & 8.26 & 3.73 & 2.16 & 1.25 \\
\hline Thailand & 92.57 & 9.37 & 83.21 & 1.16 & 0.77 & 8.46 & 80.89 & 0.14 & 64.80 & 4.37 & 50.12 & 25.03 & 1.10 & 19995.26 & 12.24 & 4.76 & 3.10 & 3.40 & 4.00 \\
\hline Taiwan & 59.08 & 0.84 & 56.73 & 0.31 & 0.83 & 12.69 & 58.31 & 0.00 & 50.99 & 7.37 & 29.75 & 11.01 & 1.02 & 13960.03 & 9.98 & 4.91 & 1.63 & 1.54 & 0.65 \\
\hline Vietnam & 48.23 & 6.32 & 41.90 & 0.34 & 0.40 & 5.08 & 54.59 & 2.84 & 48.10 & 0.00 & 41.38 & 20.49 & 1.30 & 6933.989 & 15.06 & 7.34 & 3.44 & 10.53 & 2.07 \\
\hline
\end{tabular}

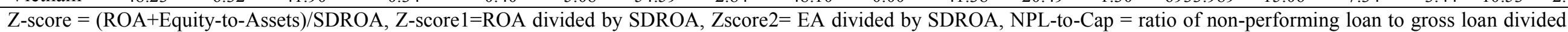

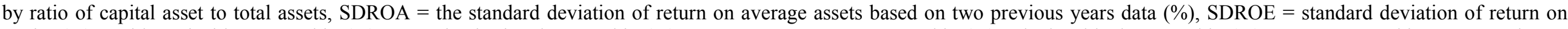

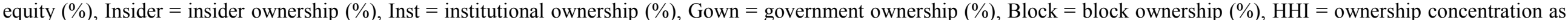

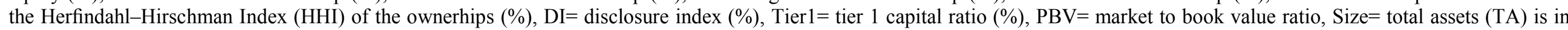

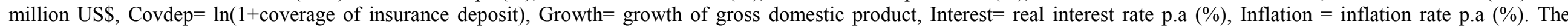
numbers for each country are average measures. 
Table 3. Disclosure index by country and by year (in percentage)

\begin{tabular}{|l|c|c|c|c|c|c|}
\hline Panel A. Dis clos ure by country & & & & \\
\hline Country & Mean & Std.Dev. & Min & Median & Max & Obs \\
\hline China & 78.27 & 20.26 & 0 & 85.7 & 95.20 & 94 \\
\hline Indonesia & 56.93 & 20.44 & 0 & 61.9 & 81.00 & 180 \\
\hline India & 54.23 & 16.39 & 0 & 57.1 & 85.70 & 270 \\
\hline Japan & 67.61 & 5.59 & 0 & 66.7 & 76.20 & 544 \\
\hline S-Korea & 76.30 & 8.76 & 47.60 & 76.20 & 95.20 & 42 \\
\hline Malaysia & 74.60 & 2.32 & 71.40 & 76.20 & 76.20 & 21 \\
\hline Philippines & 70.11 & 20.34 & 0 & 76.2 & 95.20 & 90 \\
\hline Singapore & 80.05 & 19.54 & 38.10 & 90.50 & 95.20 & 21 \\
\hline Thailand & 80.89 & 12.98 & 42.90 & 85.70 & 95.20 & 77 \\
\hline Taiwan & 58.31 & 26.81 & 0 & 66.7 & 85.70 & 82 \\
\hline Vietnam & 54.59 & 20.59 & 0 & 59.5 & 71.40 & 28 \\
\hline Total & 65.10 & 17.36 & 0 & 66.7 & 95.20 & 1449 \\
\hline Panel B. Evolution of dis clos ure & & & & \\
\hline Year & Mean & Std.Dev. & Min & Median & Max & Obs \\
\hline 2004 & 58.53 & 19.73 & 0 & 66.7 & 95.20 & 206 \\
\hline 2005 & 61.67 & 18.14 & 0 & 66.7 & 95.20 & 206 \\
\hline 2006 & 65.03 & 15.75 & 0 & 66.7 & 95.20 & 206 \\
\hline 2007 & 66.53 & 16.45 & 0 & 66.7 & 95.20 & 209 \\
\hline 2008 & 69.86 & 14.57 & 0 & 71.4 & 95.20 & 209 \\
\hline 2009 & 69.14 & 14.72 & 0 & 71.4 & 95.20 & 206 \\
\hline 2010 & 64.83 & 18.88 & 0 & 66.7 & 95.20 & 207 \\
\hline Total & 65.10 & 17.36 & 0 & 66.7 & 95.20 & 1449 \\
\hline
\end{tabular}


Table 4. Correlation matrix of bank risk, disclosure and other variables (2004-2010)

\begin{tabular}{|c|c|c|c|c|c|c|c|c|c|c|c|c|c|c|c|c|c|c|}
\hline & Z-score & $Z$-score 1 & Z-score 2 & NPL-to-Cap & SDROA & SDROE & DI & Insider & Inst & Gown & Block & HHI & PBV & Size & Tier1 & Growth & Interest & Inflation \\
\hline Zscore & 1 & & & & & & & & & & & & & & & & & \\
\hline Zscore1 & $0.7893^{*}$ & 1 & & & & & & & & & & & & & & & & \\
\hline Zscore2 & $0.9885^{*}$ & $0.7577^{*}$ & 1 & & & & & & & & & & & & & & & \\
\hline NPL-to-Cap & $-0.1295^{*}$ & $-0.2253^{*}$ & $-0.1144 *$ & 1 & & & & & & & & & & & & & & \\
\hline SDROA & $-0.9087^{*}$ & $-0.6643^{*}$ & $-0.9274 *$ & -0.0226 & 1 & & & & & & & & & & & & & \\
\hline SDROE & $-0.7579^{*}$ & $-0.5420^{*}$ & $-0.7630^{*}$ & $0.0532^{*}$ & $0.7068^{*}$ & 1 & & & & & & & & & & & & \\
\hline Disclosure (DI) & 0.0386 & 0.0269 & 0.0439 & $0.0488^{*}$ & $-0.0564^{*}$ & $-0.0720^{*}$ & 1 & & & & & & & & & & & \\
\hline Insider & -0.0381 & -0.0084 & $-0.0471^{*}$ & $-0.1379^{*}$ & $0.0985^{*}$ & 0.0274 & -0.0042 & 1 & & & & & & & & & & \\
\hline Inst & -0.0225 & $0.0743^{*}$ & -0.0376 & $-0.2063^{*}$ & $0.1812^{*}$ & -0.0034 & $0.1547 *$ & 0.0358 & 1 & & & & & & & & & \\
\hline Gown & -0.0390 & $0.1154^{*}$ & $-0.0646^{*}$ & $-0.0851^{*}$ & 0.0305 & $0.0737^{*}$ & $-0.1598^{*}$ & $-0.0573^{*}$ & $-0.3409 *$ & 1 & & & & & & & & \\
\hline Block & $-0.0620^{*}$ & $0.1486^{*}$ & $-0.0999 *$ & $-0.2535^{*}$ & $0.2248^{*}$ & $0.0822^{*}$ & -0.0252 & $0.0658^{*}$ & $0.5977^{*}$ & $0.4380^{*}$ & 1 & & & & & & & \\
\hline HHI & -0.0402 & $0.1143^{*}$ & $-0.0711^{*}$ & $-0.1507^{*}$ & $0.1403 *$ & $0.0824^{*}$ & $-0.1087^{*}$ & 0.0178 & $0.3326^{*}$ & $0.4925^{*}$ & $0.7512^{*}$ & 1 & & & & & & \\
\hline PBV & $-0.0631^{*}$ & $0.1303^{*}$ & $-0.0942 *$ & $-0.2194 *$ & $0.1495^{*}$ & $0.0577^{*}$ & 0.0134 & $0.0821^{*}$ & $0.2403^{*}$ & 0.0158 & $0.2711^{*}$ & $0.2017^{*}$ & 1 & & & & & \\
\hline Size & $0.0781^{*}$ & $0.0873^{*}$ & $0.0777^{*}$ & 0.0419 & $-0.2081^{*}$ & $-0.0670^{*}$ & $0.3262^{*}$ & -0.0419 & $-0.2429^{*}$ & $0.1195^{*}$ & $-0.2741^{*}$ & $-0.2469^{*}$ & 0.0144 & 1 & & & & \\
\hline Tier1 & $0.1594^{*}$ & $0.1299^{*}$ & $0.1466^{*}$ & $-0.2800 *$ & $0.1275^{*}$ & $-0.1630^{*}$ & -0.0382 & 0.0773* & $0.2799 *$ & $-0.0653^{*}$ & $0.2857^{*}$ & $0.1822^{*}$ & $0.0918^{*}$ & $-0.3799 *$ & 1 & & & \\
\hline Growth & -0.0426 & $0.1935^{*}$ & $-0.0797^{*}$ & $-0.2982^{*}$ & $0.1223^{*}$ & $0.0821^{*}$ & $-0.0524^{*}$ & $0.0474^{*}$ & $0.1674^{*}$ & $0.3232^{*}$ & $0.4325^{*}$ & $0.3530^{*}$ & $0.2059^{*}$ & -0.0136 & $0.1011^{*}$ & 1 & & \\
\hline Interest & $0.0857^{*}$ & $0.1856^{*}$ & $0.0603^{*}$ & $-0.1546^{*}$ & -0.0157 & $-0.0486^{*}$ & $-0.0739^{*}$ & $0.1105^{*}$ & 0.0393 & $0.2519^{*}$ & $0.2524^{*}$ & $0.2390 *$ & $0.0739 *$ & $-0.0948^{*}$ & $0.0774 *$ & $0.1526^{*}$ & 1 & \\
\hline Inflation & -0.0381 & $0.1697^{*}$ & $-0.0754^{*}$ & $-0.3348^{*}$ & $0.2038^{*}$ & 0.0439 & $-0.1645^{*}$ & $0.1116^{*}$ & $0.2428^{*}$ & $0.3288^{*}$ & $0.5664^{*}$ & $0.4622^{*}$ & $0.1498^{*}$ & $-0.3773^{*}$ & $0.3650^{*}$ & $0.4660^{*}$ & $0.2106^{*}$ & 1 \\
\hline Covdep & $-0.0533^{*}$ & 0.0419 & $-0.0784^{*}$ & -0.0113 & $0.2415^{*}$ & 0.0236 & $-0.1213^{*}$ & -0.0005 & $0.3374 *$ & $0.0921 *$ & $0.4796^{*}$ & $0.3838^{*}$ & $0.1811^{*}$ & $-0.4899 *$ & $0.4506^{*}$ & $0.0491 *$ & $0.1525^{*}$ & $0.4755^{*}$ \\
\hline
\end{tabular}

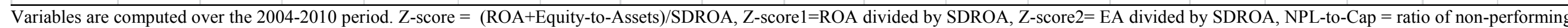

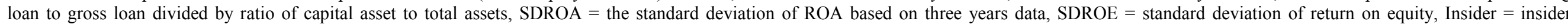

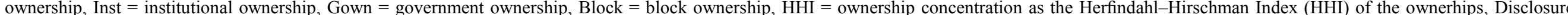

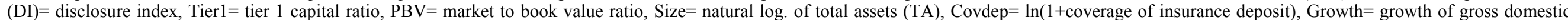
product, Interest $=$ real interest rate per annum, Inflation $=$ inflation rate p.a. Superscripts $*$ denotes statistical significant at the 0.10 levels or smaller. 
Table 5 The impact of disclosure on bank risk: Baseline IV-models

\begin{tabular}{|c|c|c|c|c|c|c|c|c|c|c|c|c|c|c|c|c|c|c|c|c|c|c|c|c|}
\hline \multirow{2}{*}{\begin{tabular}{|l|} 
Dep. Var \\
Model \\
\end{tabular}} & \multicolumn{4}{|c|}{ Z-score } & \multicolumn{4}{|c|}{ Z-score 1} & \multicolumn{4}{|c|}{ Z-score 2} & \multicolumn{4}{|c|}{ NPL to Cap } & \multicolumn{4}{|c|}{ SDROA } & \multicolumn{4}{|c|}{ SDROE } \\
\hline & (1) & (2) & (3) & (4) & (1) & (2) & (3) & (4) & (1) & (2) & (3) & (4) & (1) & (2) & (3) & (4) & (1) & (2) & (3) & (4) & (1) & & (3) & (4) \\
\hline \multirow[t]{2}{*}{\begin{tabular}{|l|} 
DI \\
\end{tabular}} & $0.104^{* * * *}$ & $0.104 * * *$ & $0.105 * * *$ & $0.102^{* * *}$ & $0.0710^{* * * *}$ & $0.0714 * * *$ & $0.0712 * * *$ & $0.0700^{* * *}$ & $0.0998^{* * *}$ & $0.0990 * * *$ & $0.101 * * *$ & $0.0975^{* * *}$ & -0.000726 & -0.000923 & -0.00102 & 0.000379 & $-0.0881 * * *$ & $-0.0870^{* * * *}$ & $-0.0890 * * *$ & $-0.0858 * * *$ & $-0.0555^{* * * *}$ & $-0.0550^{* * * *}$ & *0.0562*** & $*-0.0559 * * *$ \\
\hline & $(5.34)$ & $(5.46)$ & $(5.40)$ & (5.33) & (3.91) & (3.95) & $(3.91)$ & $(3.81)$ & (5.26) & (5.40) & $(5.32)$ & $(5.25)$ & $(-0.10)$ & $(-0.13)$ & $(-0.14)$ & $(0.05)$ & $(-5.02)$ & $(-5.14)$ & $(-5.11)$ & $(-5.01)$ & $(-3.28)$ & $(-3.47)$ & $(-3.34)$ & $(-3.35)$ \\
\hline \multirow[t]{2}{*}{ Insiders } & 0.0103 & 0.0102 & 0.00979 & 0.0100 & $0.0294 * * *$ & $0.0298 * * *$ & $0.0291 * * *$ & $0.0296^{* * *}$ & 0.0101 & 0.0101 & 0.00958 & 0.00993 & 0.00482 & 0.00470 & 0.00466 & 0.00506 & -0.0124 & -0.0124 & -0.0118 & -0.0123 & -0.00850 & -0.00846 & -0.00813 & -0.00831 \\
\hline & $(0.43)$ & $(0.42)$ & $(0.41)$ & $(0.42)$ & $(3.06)$ & $(3.05)$ & $(3.02)$ & $(3.06)$ & $(0.40)$ & $(0.40)$ & $(0.38)$ & $(0.40)$ & $(0.90)$ & $(0.87)$ & $(0.87)$ & $(0.96)$ & $(-0.49)$ & $(-0.49)$ & $(-0.47)$ & $(-0.49)$ & $(-0.33)$ & $(-0.33)$ & $(-0.32)$ & $(-0.32)$ \\
\hline Inst & $(-0.76)$ & & & & $(-1.10)$ & & & & $(-0.90)$ & & & & $(0.16)$ & & & & $(1.03)$ & & & & $(0.91)$ & & & \\
\hline \multirow{2}{*}{ Gown } & & $-0.0216^{* *}$ & & & & $-0.0196^{*}$ & & & & $-0.0207 * *$ & & & & $-0.00879 * * *$ & & & & $0.0204 * *$ & & & & 0.0117 & & \\
\hline & & $(-2.36)$ & & & & $(-1.93)$ & & & & $(-2.31)$ & & & & $(-3.60)$ & & & & $(2.38)$ & & & & $(1.48)$ & & \\
\hline \multirow[t]{2}{*}{ Block } & & & $-0.00820 *$ & & & & $-0.00756 * *$ & & & & $-0.00867 * *$ & & & & -0.000710 & & & & $0.00931^{* *}$ & & & & $0.00675^{*}$ & \\
\hline & & & $(-1.93)$ & & & & $(-2.14)$ & & & & $(-2.16)$ & & & & $(-0.56)$ & & & & $(2.41)$ & & & & $(1.75)$ & \\
\hline HHI & & & & -0.00531 & & & & -0.00618 & & & & -0.00569 & & & & -0.00187 & & & & 0.00637 & & & & 0.00138 \\
\hline \multirow[t]{2}{*}{ PBV } & -0.0214 & -0.0394 & -0.0321 & -0.0295 & 0.0786 & 0.0592 & 0.0660 & 0.0646 & -0.0135 & -0.0312 & -0.0247 & -0.0223 & 0.0211 & 0.00959 & 0.0211 & 0.0196 & -0.00835 & 0.0104 & 0.00351 & 0.00111 & -0.0139 & -0.00944 & -0.00462 & -0.0115 \\
\hline & $(-0.35)$ & $(-0.66)$ & $(-0.52)$ & $(-0.49)$ & (1.05) & $(0.82)$ & $(0.89)$ & $(0.87)$ & $(-0.23)$ & $(-0.54)$ & $(-0.41)$ & $(-0.38)$ & $(0.63)$ & $(0.29)$ & $(0.63)$ & $(0.57)$ & $(-0.15)$ & $(0.19)$ & $(0.06)$ & $(0.02)$ & $(-0.29)$ & $(-0.20)$ & $(-0.10)$ & $(-0.24)$ \\
\hline \multirow[t]{2}{*}{ Size } & 0.0479 & 0.0491 & 0.0447 & 0.0467 & 0.0449 & 0.0441 & 0.0425 & 0.0447 & 0.0459 & 0.0466 & 0.0423 & 0.0443 & 0.0318 & 0.0330 & 0.0318 & 0.0321 & -0.0543 & -0.0546 & -0.0504 & -0.0529 & -0.0787 & -0.0785 & -0.0752 & -0.0824 \\
\hline & $(0.56)$ & $(0.58)$ & $(0.53)$ & $(0.56)$ & $(0.63)$ & $(0.62)$ & $(0.60)$ & $(0.63)$ & $(0.56)$ & $(0.58)$ & $(0.52)$ & $(0.56)$ & $(0.81)$ & $(0.84)$ & $(0.81)$ & $(0.83)$ & $(-0.76)$ & $(-0.78)$ & $(-0.72)$ & $(-0.76)$ & $(-1.12)$ & $(-1.13)$ & $(-1.08)$ & $(-1.17)$ \\
\hline \multirow[t]{2}{*}{ Tier1 } & $0.0461^{*}$ & $0.0467 *$ & $0.0478^{*}$ & $0.0482^{*}$ & 0.00782 & 0.00882 & 0.00804 & 0.0112 & $0.0409^{*}$ & $0.0415^{*}$ & $0.0426^{*}$ & $0.0431 *$ & -0.00754 & -0.00813 & -0.00781 & -0.00692 & 0.00109 & 0.000501 & -0.000691 & -0.00134 & -0.0186 & -0.0192 & -0.0201 & -0.0183 \\
\hline & $(1.82)$ & $(1.87)$ & $(1.89)$ & $(1.92)$ & $(0.29)$ & $(0.33)$ & $(0.30)$ & $(0.42)$ & $(1.69)$ & $(1.73)$ & $(1.76)$ & $(1.79)$ & $(-0.82)$ & $(-0.88)$ & $(-0.85)$ & $(-0.75)$ & $(0.05)$ & $(0.02)$ & $(-0.03)$ & $(-0.06)$ & $(-0.95)$ & $(-0.98)$ & $(-1.02)$ & $(-0.92)$ \\
\hline \multirow[t]{2}{*}{ Growth } & $-0.0712 * *$ & $-0.0695^{* *}$ & $-0.0714^{* *}$ & $-0.0681^{* *}$ & $-0.0844^{* * *}$ & $-0.0831^{* * *}$ & $-0.0838 * * *$ & $-0.0803^{* *}$ & $-0.0682^{* *}$ & $-0.0665 * *$ & $-0.0683^{* *}$ & $-0.0648 * *$ & $0.0302^{* * * *}$ & $0.0321^{* * *}$ & $0.0305 * * *$ & $0.0313^{* * *}$ & $0.0633^{* *}$ & $0.0613^{* *}$ & $0.0632 * *$ & $0.0595^{* *}$ & $0.0761^{* * * *}$ & $0.0754^{* * *}$ & $0.0760^{* * *}$ & $* 0.0741^{* *}$ \\
\hline & $(-2.36)$ & $(-2.35)$ & $(-2.38)$ & $(-2.24)$ & $(-2.74)$ & $(-2.73)$ & $(-2.75)$ & $(-2.56)$ & $(-2.35)$ & $(-2.33)$ & $(-2.37)$ & $(-2.21)$ & $(2.91)$ & $(3.09)$ & $(2.94)$ & $(2.94)$ & \begin{tabular}{|l}
$(2.31)$ \\
\end{tabular} & $(2.28)$ & $(2.32)$ & $(2.15)$ & $(2.61)$ & $(2.60)$ & $(2.63)$ & $(2.50)$ \\
\hline \multirow{2}{*}{ Interest } & 0.0445 & $0.0517^{*}$ & 0.0456 & 0.0442 & $0.0633^{*}$ & $0.0702^{* *}$ & $0.0645^{* *}$ & $0.0646^{*}$ & 0.0432 & $0.0502^{*}$ & 0.0444 & 0.0429 & 0.0144 & 0.0172 & 0.0144 & 0.0153 & -0.0456 & $-0.0525^{*}$ & -0.0468 & -0.0453 & -0.0224 & -0.0261 & -0.0232 & -0.0240 \\
\hline & $(1.38)$ & $(1.68)$ & $(1.41)$ & $(1.38)$ & $(1.92)$ & $(2.30)$ & $(1.98)$ & $(1.96)$ & $(1.39)$ & $(1.69)$ & $(1.43)$ & $(1.39)$ & $(1.29)$ & $(1.56)$ & $(1.29)$ & $(1.36)$ & $(-1.56)$ & $(-1.89)$ & $(-1.61)$ & $(-1.56)$ & $(-0.88)$ & $(-1.07)$ & $(-0.92)$ & $(-0.95)$ \\
\hline \multirow[t]{2}{*}{ Inflation } & -0.0456 & -0.0418 & -0.0488 & $-0.0489^{*}$ & -0.0199 & -0.0167 & -0.0226 & -0.0237 & -0.0442 & -0.0403 & -0.0475 & $-0.0478 *$ & 0.00437 & 0.00429 & 0.00407 & 0.00315 & 0.0315 & 0.0278 & 0.0351 & 0.0356 & $0.0453^{*}$ & $0.0417^{*}$ & $0.0478^{*}$ & $0.0437^{*}$ \\
\hline & $(-1.54)$ & $(-1.46)$ & $(-1.63)$ & $(-1.65)$ & $(-0.68)$ & $(-0.58)$ & $(-0.77)$ & $(-0.79)$ & $(-1.53)$ & $(-1.45)$ & $(-1.63)$ & $(-1.65)$ & $(0.40)$ & $(0.40)$ & $(0.37)$ & $(0.28)$ & $(1.16)$ & (1.06) & $(1.28)$ & $(1.31)$ & $(1.79)$ & $(1.70)$ & $(1.87)$ & $(1.70)$ \\
\hline Covdep & $-0.168 * *$ & $-0.1477^{* *}$ & $-0.161 * *$ & $-0.166 * *$ & $-0.194 * * *$ & $-0.173 * *$ & $-0.186 * * *$ & $-0.191 * * *$ & $-0.162 * *$ & $-0.142 * *$ & $-0.154 * *$ & $-0.160^{* *}$ & 0.0318 & 0.0413 & 0.0329 & 0.0338 & $0.146^{* *}$ & $0.126^{*}$ & $0.138 * *$ & $0.143^{* *}$ & $0.182 * * *$ & $0.169^{* *}$ & $0.175^{* *}$ & $0.180^{* * *}$ \\
\hline $\mathrm{N}$ & 965 & 970 & 969 & 962 & 886 & 890 & 889 & 884 & 965 & 970 & 969 & 962 & 963 & 968 & 967 & 960 & 965 & 970 & 969 & 962 & 952 & 957 & 956 & 950 \\
\hline F-stat & 7.7487 & 8.1976 & 7.9523 & 7.3638 & 7.1001 & 7.5552 & 7.4833 & 6.9530 & 7.7291 & 8.2068 & 7.9603 & 7.3561 & 13.3714 & 14.5107 & 13.0349 & 14.6753 & 6.9077 & 7.4285 & 7.1785 & 6.6185 & 6.7737 & 7.0781 & 7.1785 & 6.6185 \\
\hline $\begin{array}{l}\text { Hansen J } \\
\text { stat.(overid. test) }\end{array}$ & 0.002 & 0.017 & 0.001 & 0.000 & 0.045 & 0.116 & 0.067 & 0.043 & 0.000 & 0.009 & 0.000 & 0.001 & 0.316 & 0.418 & 0.282 & 0.303 & 0.001 & 0.002 & 0.004 & 0.005 & 0.612 & 0.678 & 0.622 & 0.677 \\
\hline $\begin{array}{l}\text { Endogeneity test, } \\
\text { Chi-sq: DI }\end{array}$ & $32.267^{* * *}$ & $32.321 * * *$ & $32.395 * * *$ & $30.818^{* * * *}$ & $13.733 * * *$ & $13.979 * * *$ & $13.495 * * *$ & $13.023^{* * *}$ & $29.959 * * *$ & $29.998 * * *$ & $29.983^{* * *}$ & $28.546^{* * *}$ & 0.075 & 0.130 & 0.100 & 0.020 & $27.201 * * *$ & $27.020^{* * *}$ & $27.329^{* * * *}$ & $25.950^{* * * *}$ & $10.139 * * *$ & $10.980^{* * *}$ & $10.341^{* * *}$ & * $10.308^{* * *}$ \\
\hline
\end{tabular}

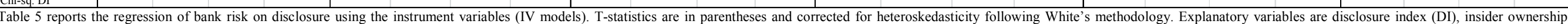

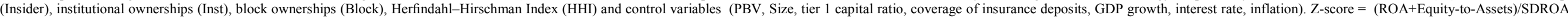

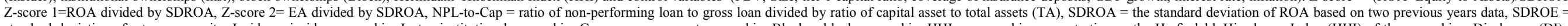

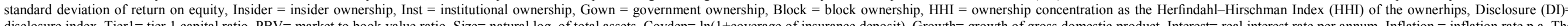

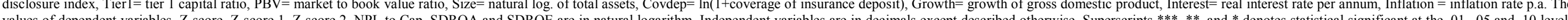

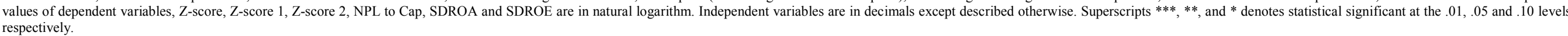


Table 6. The combined impact of disclosure and ownership on bank risk: Augmented IV-models

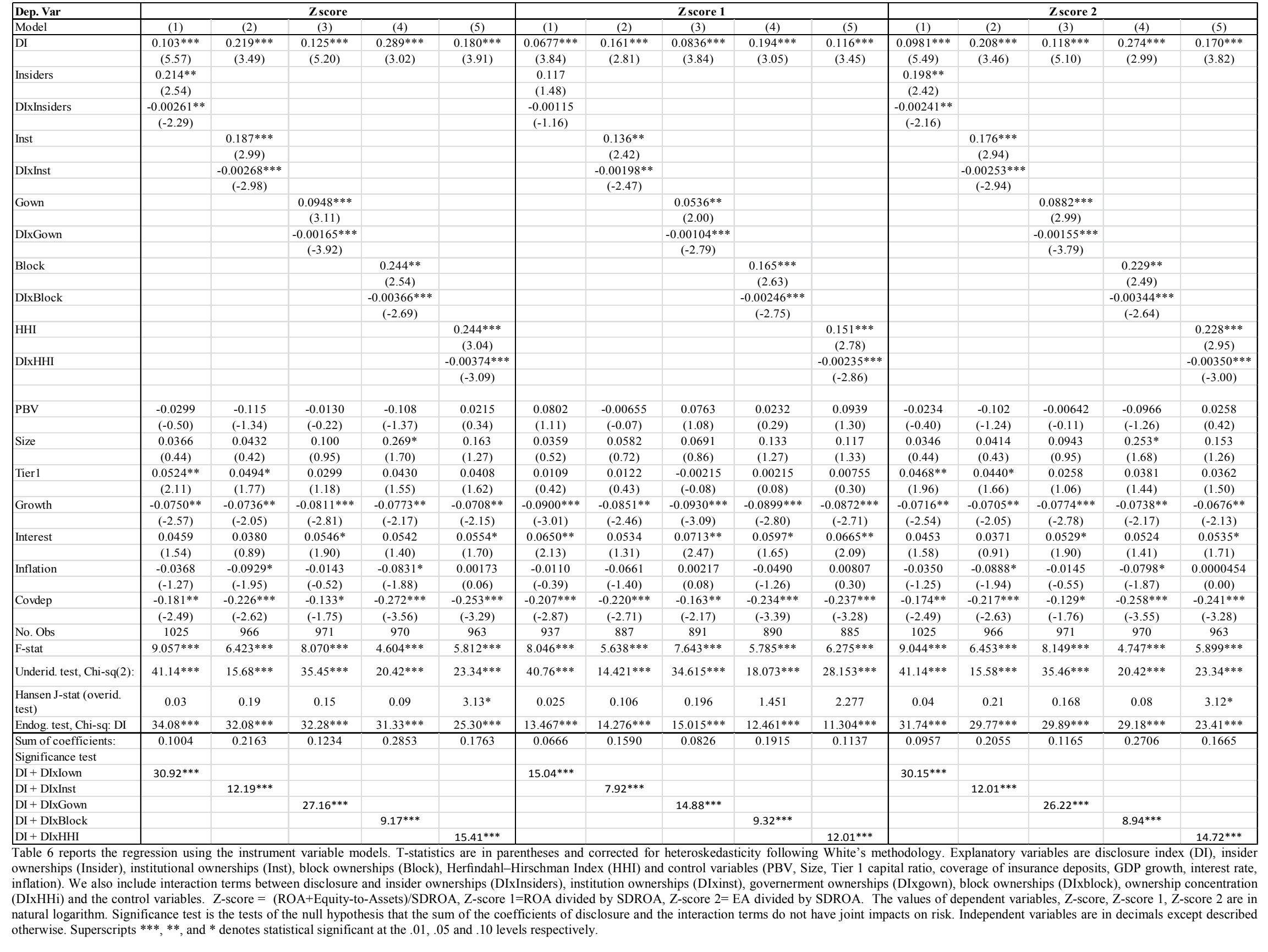


Table 6. The combined impact of disclosure and ownership on bank risk: Augmented IV-models (cont'd)

\begin{tabular}{|c|c|c|c|c|c|c|c|c|c|c|c|c|c|c|c|}
\hline \multirow{2}{*}{\begin{tabular}{|l|} 
Dep. Variables \\
Model \\
\end{tabular}} & \multicolumn{5}{|c|}{ NPL to Cap } & \multicolumn{5}{|c|}{ SDROA } & \multicolumn{5}{|c|}{ SDROE } \\
\hline & (1) & (2) & (3) & (4) & (5) & (1) & (2) & (3) & (4) & (5) & (1) & (2) & (3) & (4) & (5) \\
\hline & -0.000968 & -0.00527 & -0.000376 & -0.00502 & 0.000682 & $-0.0855^{* * * *}$ & $-0.189^{* * *}$ & $-0.103^{* * * *}$ & $-0.244 * * *$ & $-0.151 * * *$ & $-0.0573 * * *$ & $-0.124 * * *$ & $-0.0673 * * *$ & $-0.140^{* *}$ & $-0.112 * * *$ \\
\hline & $(-0.13)$ & $(-0.33)$ & $(-0.05)$ & $(-0.24)$ & $(0.05)$ & $(-5.24)$ & $(-3.41)$ & $(-4.85)$ & $(-2.86)$ & $(-3.65)$ & $(-3.56)$ & $(-2.64)$ & $(-3.41)$ & $(-2.26)$ & $(-2.85)$ \\
\hline \multirow[t]{2}{*}{ Insiders } & -0.0415 & & & & & $-0.168^{* *}$ & & & & & -0.0541 & & & & \\
\hline & $(-1.33)$ & & & & & $(-2.12)$ & & & & & $(-0.74)$ & & & & \\
\hline \multirow[t]{2}{*}{ DIxInsiders } & 0.000556 & & & & & $0.00200^{*}$ & & & & & 0.000587 & & & & \\
\hline & $(1.42)$ & & & & & $(1.87)$ & & & & & $(0.60)$ & & & & \\
\hline \multirow{2}{*}{ Inst } & & -0.00723 & & & & & $-0.164 * * *$ & & & & & $-0.109^{* *}$ & & & \\
\hline & & $(-0.50)$ & & & & & $(-2.96)$ & & & & & $(-2.34)$ & & & \\
\hline \multirow{2}{*}{ DIxInst } & & 0.000105 & & & & & $0.00236 * * *$ & & & & & $0.00159 * *$ & & & \\
\hline & & $(0.50)$ & & & & & $(2.97)$ & & & & & $(2.36)$ & & & \\
\hline \multirow[t]{2}{*}{ Gown } & & & -0.0117 & & & & & $-0.0722 * * *$ & & & & & $-0.0475^{* * *}$ & & \\
\hline & & & $(-1.17)$ & & & & & $(-2.63)$ & & & & & $(-1.98)$ & & \\
\hline \multirow[t]{2}{*}{ DIxGown } & & & 0.0000411 & & & & & $0.00132 * * *$ & & & & & $0.000841 * *$ & & \\
\hline & & & $(0.29)$ & & & & & $(3.49)$ & & & & & $(2.48)$ & & \\
\hline \multirow{2}{*}{ Block } & & & & -0.00892 & & & & & $-0.203 * *$ & & & & & $-0.116^{*}$ & \\
\hline & & & & $(-0.45)$ & & & & & $(-2.37)$ & & & & & $(-1.90)$ & \\
\hline \multirow[t]{2}{*}{ DIxBlock } & & & & 0.000115 & & & & & $0.00307 * *$ & & & & & $0.00177^{* *}$ & \\
\hline & & & & $(0.40)$ & & & & & $(2.54)$ & & & & & $(2.01)$ & \\
\hline \multirow[t]{2}{*}{ HHI } & & & & & -0.00728 & & & & & $-0.204 * * *$ & & & & & $-0.157 * *$ \\
\hline & & & & & $(-0.36)$ & & & & & $(-2.83)$ & & & & & $(-2.39)$ \\
\hline \multirow[t]{3}{*}{ DIxHHI } & & & & & 0.0000793 & & & & & $0.00315^{* * *}$ & & & & & \\
\hline & & & & & $(0.26)$ & & & & & $(2.89)$ & & & & & $0.00237^{* *}$ \\
\hline & & & & & & & & & & & & & & & $(2.37)$ \\
\hline \multirow[t]{2}{*}{ PBV } & 0.0257 & 0.0244 & 0.00815 & 0.0217 & 0.0171 & 0.00285 & 0.0742 & -0.0105 & 0.0681 & -0.0422 & -0.0313 & 0.0470 & -0.0203 & 0.0355 & -0.0397 \\
\hline & $(0.79)$ & $(0.69)$ & $(0.25)$ & $(0.64)$ & $(0.51)$ & $(0.05)$ & $(0.98)$ & $(-0.20)$ & $(0.98)$ & $(-0.73)$ & $(-0.62)$ & $(0.74)$ & $(-0.43)$ & $(0.61)$ & $(-0.77)$ \\
\hline Size & 0.0196 & 0.0309 & 0.0324 & 0.0278 & 0.0303 & -0.0420 & -0.0502 & -0.0952 & $-0.239^{*}$ & -0.150 & -0.0534 & -0.0779 & -0.106 & $-0.182^{*}$ & -0.161 \\
\hline & $(0.51)$ & $(0.78)$ & $(0.82)$ & $(0.65)$ & $(0.73)$ & $(-0.61)$ & $(-0.61)$ & $(-1.11)$ & $(-1.81)$ & $(-1.41)$ & $(-0.72)$ & $(-0.94)$ & $(-1.33)$ & $(-1.72)$ & $(-1.52)$ \\
\hline Tier1 & -0.0138 & -0.00797 & -0.00790 & -0.00772 & -0.00686 & -0.00125 & -0.00162 & 0.0141 & 0.00349 & 0.00517 & -0.0121 & -0.0198 & -0.0104 & -0.0162 & -0.0140 \\
\hline & $(-1.50)$ & $(-0.85)$ & $(-0.87)$ & $(-0.83)$ & $(-0.75)$ & $(-0.06)$ & $(-0.07)$ & $(0.64)$ & $(0.15)$ & $(0.24)$ & $(-0.61)$ & $(-0.93)$ & $(-0.53)$ & $(-0.81)$ & $(-0.68)$ \\
\hline Growth & $0.0267 * * *$ & $0.0298^{* * * *}$ & $0.0321^{* * * *}$ & $0.0305 * * *$ & $0.0316^{* * * *}$ & $0.0666 * *$ & $0.0658^{* *}$ & $0.0711^{* * * *}$ & $0.0684 * *$ & $0.0626^{* * *}$ & $0.0835 * * *$ & $0.0759 * *$ & $0.0805^{* * *}$ & $0.0798^{* * *}$ & $0.0712^{* *}$ \\
\hline & $(2.65)$ & $(2.90)$ & $(3.16)$ & $(2.96)$ & $(2.97)$ & $(2.51)$ & $(2.04)$ & $(2.70)$ & $(2.15)$ & $(2.10)$ & $(2.89)$ & $(2.46)$ & $(2.80)$ & $(2.71)$ & $(2.25)$ \\
\hline Interest & 0.00731 & 0.0149 & 0.0166 & 0.0135 & 0.0145 & $-0.0464 *$ & -0.0399 & $-0.0548^{* *}$ & -0.0539 & $-0.0548^{*}$ & -0.0137 & -0.0174 & -0.0276 & -0.0274 & -0.0299 \\
\hline & $(0.68)$ & $(1.30)$ & $(1.53)$ & $(1.24)$ & $(1.30)$ & $(-1.73)$ & $(-1.05)$ & $(-2.09)$ & $(-1.58)$ & $(-1.89)$ & $(-0.57)$ & $(-0.57)$ & $(-1.18)$ & $(-1.03)$ & $(-1.13)$ \\
\hline Inflation & 0.00259 & 0.00640 & 0.00331 & 0.00428 & 0.00112 & 0.0224 & $0.0730^{*}$ & 0.00554 & 0.0640 & -0.00777 & $0.0421^{*}$ & $0.0756^{* *}$ & 0.0286 & $0.0626^{*}$ & 0.0166 \\
\hline & $(0.24)$ & $(0.50)$ & $(0.32)$ & $(0.36)$ & $(0.11)$ & $(0.85)$ & $(1.72)$ & $(0.22)$ & $(1.62)$ & $(-0.30)$ & $(1.68)$ & $(2.01)$ & $(1.22)$ & $(1.90)$ & $(0.67)$ \\
\hline Covdep & 0.0408 & 0.0342 & 0.0413 & 0.0370 & 0.0367 & $0.154 * *$ & $0.197^{* * *}$ & $0.116^{*}$ & $0.230^{* * *}$ & $0.216^{* * * *}$ & $0.173 * *$ & $0.214^{* * * *}$ & $0.161 * *$ & $0.232 * * *$ & $0.228 * * *$ \\
\hline & $(1.53)$ & $(1.32)$ & $(1.50)$ & (1.44) & $(1.41)$ & $(2.38)$ & $(2.59)$ & $(1.69)$ & $(3.42)$ & $(3.12)$ & $(2.50)$ & $(2.95)$ & $(2.28)$ & $(3.54)$ & $(3.09)$ \\
\hline No. obs. & 1023 & 964 & 969 & 968 & 961 & 1025 & 966 & 971 & 970 & 963 & 1006 & 953 & 958 & 957 & 951 \\
\hline F-stat & $17.180^{* * *}$ & $13.187^{* * *}$ & $14.881^{* * *}$ & $13.519^{* * *}$ & $15.496^{* * *}$ & $7.934 * * *$ & $5.631^{* * *}$ & $7.669 * * *$ & $4.378^{* * *}$ & $5.437^{* * *}$ & $7.035^{* * * *}$ & $5.519^{* * *}$ & $7.424 * * *$ & $6.022 * * *$ & $5.546^{* * *}$ \\
\hline Underid. test, Chi-sq(2): & $46.883 * * *$ & $20.487 * * *$ & $39.940 * * *$ & $26.069 * * *$ & $34.961 * * *$ & $41.140 * * *$ & $15.581^{* * *}$ & $35.455^{* * *}$ & $20.418 * * *$ & $23.345 * * *$ & $40.382 * * *$ & $15.785^{* * *} *$ & $35.335 * * *$ & $21.549^{* * *}$ & $23.448 * * *$ \\
\hline Hansen J-stat (overid. test) & 0.187 & 0.307 & 0.548 & 0.533 & 0.569 & 0.067 & 0.243 & 0.138 & 0.064 & $2.729 *$ & 0.042 & 0.162 & 0.173 & 0.466 & 0.221 \\
\hline Endogeneity test, Chi-sq: DI & 0.028 & 0.090 & 0.045 & 0.001 & 0.056 & $28.806 * * *$ & $27.163 * * *$ & $27.369^{* * * *}$ & $26.749 * * *$ & $21.032 * * *$ & $12.890^{* * * *}$ & $11.090^{* * * *}$ & $12.463 * * *$ & $8.534 * * *$ & $11.810^{* * * *}$ \\
\hline Sum of coefficients: & -0.0004 & -0.0052 & -0.0003 & -0.0049 & 0.0008 & -0.0835 & -0.1866 & -0.1017 & -0.2409 & -0.1479 & -0.0567 & -0.1224 & -0.0665 & -0.1382 & -0.1096 \\
\hline Significance test: & & & & & & & & & & & & & & & \\
\hline DI + DIxlown & 0.00 & & & & & $27.75^{* * *}$ & & & & & $13.15^{* * *}$ & & & & \\
\hline DI + DIxInst & & 0.11 & & & & & $11.68^{* * *}$ & & & & & $7.00^{* * *}$ & & & \\
\hline DI + DIxGown & & & 0.00 & & & & & $23.71 * * *$ & & & & & $11.71 * * *$ & & \\
\hline DI + DIxBlock & & & & 0.06 & & & & & $8.19^{* * * *}$ & & & & & $5.12^{* *}$ & \\
\hline DI + DIxHHI & & & & & 0.00 & & & & & $13.43 * * *$ & & & & & $8.19 * * *$ \\
\hline
\end{tabular}


Table 7. Decomposing disclosure: Impact of disclosure components on risk

\begin{tabular}{|c|c|c|c|c|c|c|c|c|c|c|c|c|c|c|c|c|c|c|}
\hline \multirow{2}{*}{$\begin{array}{l}\text { Dep. Var } \\
\text { Model } \\
\end{array}$} & \multicolumn{6}{|c|}{ Z score } & \multicolumn{6}{|c|}{ Z score 1} & \multicolumn{6}{|c|}{ Z score 2} \\
\hline & (1) & (2) & (3) & (4) & (5) & (6) & (1) & (2) & (3) & (4) & (5) & (6) & (1) & (2) & (3) & (4) & (5) & (6) \\
\hline \multirow[t]{2}{*}{ DILoan } & $0.0848^{* * * *}$ & & & & & & $0.0648^{* * *}$ & & & & & & $0.0810^{* * * *}$ & & & & & \\
\hline & $(5.14)$ & & & & & & $(3.70)$ & & & & & & $(5.13)$ & & & & & \\
\hline \multirow[t]{2}{*}{ DIEA } & & $0.0331^{* * * *}$ & & & & & & $0.0269 * * *$ & & & & & & $0.0311^{* * *}$ & & & & \\
\hline & & $(5.32)$ & & & & & & $(3.51)$ & & & & & & $(4.99)$ & & & & \\
\hline \multirow[t]{2}{*}{ DIDep } & & & $0.113^{* * *}$ & & & & & & $0.0918^{* * *}$ & & & & & & $0.108^{* * *}$ & & & \\
\hline & & & $(3.76)$ & & & & & & $(2.73)$ & & & & & & $(3.79)$ & & & \\
\hline \multirow[t]{2}{*}{ DIFund } & & & & $0.122^{*}$ & & & & & & -0.0668 & & & & & & $0.0699^{*}$ & & \\
\hline & & & & $(1.65)$ & & & & & & $(-0.74)$ & & & & & & $(1.95)$ & & \\
\hline \multirow[t]{2}{*}{ DIMemo } & & & & & $0.0657^{* * *}$ & & & & & & $0.0547^{* * *}$ & & & & & & $0.0628^{* * *}$ & \\
\hline & & & & & $(5.37)$ & & & & & & $(3.62)$ & & & & & & $(5.35)$ & \\
\hline DIIS & & & & & & $(2.90)$ & & & & & & $(2.32)$ & & & & & & $(2.90)$ \\
\hline \multirow[t]{2}{*}{ PBV } & 0.0153 & 0.0190 & 0.0860 & -0.169 & -0.0248 & -0.125 & 0.123 & 0.0934 & $0.203^{* *}$ & 0.297 & 0.0871 & 0.00477 & 0.0196 & 0.0272 & 0.0871 & -0.0668 & -0.0188 & -0.115 \\
\hline & $(0.22)$ & $(0.34)$ & $(0.89)$ & $(-0.97)$ & $(-0.38)$ & $(-1.20)$ & (1.59) & $(1.23)$ & $(2.01)$ & (1.46) & $(1.17)$ & $(0.05)$ & $(0.29)$ & $(0.49)$ & $(0.94)$ & $(-0.73)$ & $(-0.29)$ & $(-1.13)$ \\
\hline \multirow[t]{2}{*}{ Size } & -0.105 & -0.0148 & -0.243 & -0.0876 & -0.102 & -0.140 & -0.0287 & 0.0275 & -0.134 & 0.0522 & -0.0403 & -0.0628 & -0.100 & -0.00825 & -0.232 & -0.0571 & -0.0980 & -0.134 \\
\hline & $(-1.42)$ & $(-0.20)$ & $(-1.51)$ & $(-0.48)$ & $(-1.31)$ & $(-0.97)$ & $(-0.36)$ & $(0.35)$ & $(-0.88)$ & $(0.59)$ & $(-0.55)$ & $(-0.89)$ & $(-1.39)$ & $(-0.11)$ & $(-1.52)$ & $(-0.48)$ & $(-1.29)$ & $(-0.95)$ \\
\hline \multirow[t]{2}{*}{ Tier1 } & $0.0488^{*}$ & 0.0254 & $0.0923^{* *}$ & $0.140^{*}$ & 0.0104 & 0.0180 & 0.0180 & -0.00159 & 0.0576 & -0.0615 & -0.0110 & -0.00564 & $0.0434^{*}$ & 0.0191 & $0.0851^{* *}$ & $0.0888^{* *}$ & 0.00682 & 0.0140 \\
\hline & $(1.77)$ & $(1.05)$ & $(2.18)$ & $(1.85)$ & $(0.41)$ & $(0.56)$ & $(0.63)$ & $(-0.06)$ & $(1.28)$ & $(-0.72)$ & $(-0.41)$ & $(-0.18)$ & $(1.65)$ & $(0.80)$ & $(2.11)$ & $(2.16)$ & $(0.28)$ & $(0.46)$ \\
\hline \multirow[t]{2}{*}{ Growth } & $-0.0651^{*}$ & $-0.107^{* * *}$ & $-0.108^{* * * *}$ & $-0.200^{* * *}$ & $-0.0792^{* * *}$ & $-0.101^{* * *}$ & $-0.0727 * *$ & $-0.105^{* * *}$ & $-0.0947 * *$ & $-0.0901^{*}$ & $-0.0768^{* *}$ & $-0.0877 * *$ & $-0.0623^{*}$ & $-0.0975^{* * *}$ & $-0.103^{* * * *}$ & $-0.162^{* * *}$ & $-0.0757 * * *$ & $-0.0966^{* * * *}$ \\
\hline & $(-1.95)$ & $(-3.65)$ & $(-2.77)$ & $(-2.82)$ & $(-2.66)$ & $(-2.77)$ & $(-2.21)$ & $(-3.31)$ & $(-2.50)$ & $(-1.93)$ & $(-2.41)$ & $(-2.18)$ & $(-1.94)$ & $(-3.35)$ & $(-2.76)$ & $(-3.41)$ & $(-2.64)$ & $(-2.75)$ \\
\hline \multirow[t]{2}{*}{ Interest } & $0.0655^{*}$ & 0.0243 & $0.131^{* * *}$ & 0.0859 & 0.0312 & 0.0519 & $0.0819^{* *}$ & 0.0458 & $0.146^{* * *}$ & 0.0586 & 0.0524 & $0.0840^{*}$ & $0.0640^{* *}$ & 0.0254 & $0.126^{* * *}$ & $0.0718^{*}$ & 0.0312 & 0.0510 \\
\hline & $(1.95)$ & $(0.93)$ & $(2.99)$ & $(1.40)$ & $(0.94)$ & $(0.98)$ & $(2.47)$ & $(1.43)$ & $(3.34)$ & $(1.39)$ & $(1.62)$ & $(1.91)$ & $(1.97)$ & $(0.95)$ & $(3.01)$ & $(1.76)$ & $(0.98)$ & $(1.00)$ \\
\hline \multirow[t]{2}{*}{ Covdep } & $-0.271 * * *$ & $-0.182^{* * *}$ & $-0.244 * * *$ & $-0.336^{* *}$ & -0.0735 & $-0.268^{* * *}$ & $-0.296^{* * *}$ & $-0.190^{* * *}$ & $-0.295 * * *$ & $-0.207^{* *}$ & -0.114 & $-0.298^{* * *}$ & $-0.260^{* * *}$ & $-0.169^{* * * *}$ & $-0.234^{* * *}$ & $-0.286^{* * * *}$ & -0.0713 & $-0.257 * * *$ \\
\hline & $(-4.02)$ & $(-2.76)$ & $(-2.59)$ & $(-2.57)$ & $(-0.93)$ & $(-2.65)$ & $(-4.22)$ & $(-2.63)$ & $(-3.21)$ & $(-2.13)$ & $(-1.35)$ & $(-3.01)$ & $(-4.00)$ & $(-2.64)$ & $(-2.59)$ & $(-3.16)$ & $(-0.93)$ & $(-2.64)$ \\
\hline No. obs & 1027 & 1027 & 1027 & 963 & 1027 & 1027 & 939 & 885 & 939 & 880 & 939 & 939 & 1027 & 963 & 1027 & 957 & 1027 & 1027 \\
\hline F-stat & $10.02^{* * *}$ & $8.46^{* * *}$ & $8.30^{* * * *}$ & $1.23^{* * * *}$ & $10.63^{* * *}$ & $7.65^{* * * *}$ & $8.31^{* * * *}$ & $6.78^{* * * *}$ & $7.29 * * *$ & $3.55^{* * *}$ & $8.75^{* * *}$ & $7.11^{* * * *}$ & $9.99^{* * *}$ & $6.88^{* * * *}$ & $8.33^{* * *}$ & $2.39^{* * *}$ & $10.73^{* * *}$ & $7.64^{* * *}$ \\
\hline Underid.test, Chi-sq(2): & $32.025 * * *$ & $62.103^{* * *}$ & $15.326^{* * * *}$ & 3.566 & $30.174^{* * *}$ & $10.444^{* * *}$ & $33.114^{* * *}$ & $56.113^{* * *}$ & $12.793^{* * *}$ & 2.660 & $29.927 * * *$ & $6.534^{* *}$ & $32.025 * * *$ & $58.708^{* * *}$ & $15.326^{* * *}$ & $7.313^{*}$ & $30.174 * * *$ & $10.444^{* * *}$ \\
\hline Hansen J-stat. (overid. test) & 1.517 & $9.485^{* * *}$ & 0.025 & $9.031^{* *}$ & 0.002 & 0.236 & 0.047 & 3.370 & 0.290 & 10.730 & 0.116 & 0.667 & 1.520 & $10.078^{* * *}$ & 0.031 & $4.922^{*}$ & 0.004 & 0.225 \\
\hline Endog.test, Chi-sq: DI & $39.559^{* * *}$ & $29.749 * * *$ & $45.954^{* * *}$ & $8.445^{* * *}$ & $39.643 * * *$ & $42.452^{* * *}$ & $16.173^{* * *}$ & $8.482 * * *$ & $19.326^{* * *}$ & 0.402 & $16.318^{* * *}$ & $16.209^{* * *}$ & $38.018^{* * *}$ & $24.640^{* * *}$ & $44.300^{* * *}$ & $5.662 * *$ & $37.074 * * *$ & $40.621^{* * *}$ \\
\hline
\end{tabular}

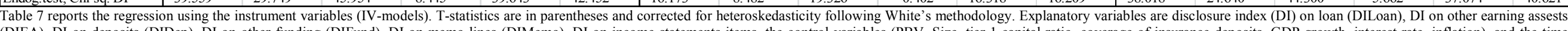

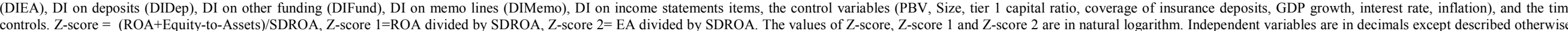
Superscripts ***,**, and * denotes statistical significant at the $0.01,0.05$ and 0.10 levels respectively. 
Table 7. Decomposing disclosure: Impact of disclosure components on risk (cont'd)

\begin{tabular}{|c|c|c|c|c|c|c|c|c|c|c|c|c|c|c|c|c|c|c|}
\hline \multirow{2}{*}{$\frac{\text { Dep. Var }}{\text { Model }}$} & \multicolumn{6}{|c|}{ NPL to Cap } & \multicolumn{6}{|c|}{ SDROA } & \multicolumn{6}{|c|}{ SDROE } \\
\hline & (1) & (2) & (3) & (4) & (5) & (6) & (1) & (2) & (3) & (4) & (5) & (6) & (1) & (2) & (3) & (4) & (5) & (6) \\
\hline \multirow[t]{2}{*}{ DILoan } & -0.00238 & & & & & & $-0.0725^{* * *}$ & & & & & & $-0.0485^{* * *}$ & & & & & \\
\hline & $(-0.43)$ & & & & & & $(-5.08)$ & & & & & & $(-3.43)$ & & & & & \\
\hline \multirow[t]{2}{*}{ DIEA } & & -0.00109 & & & & & & $-0.0272^{* * *}$ & & & & & & $-0.0184 * * *$ & & & & \\
\hline & & $(-0.41)$ & & & & & & $(-4.78)$ & & & & & & $(-3.27)$ & & & & \\
\hline \multirow[t]{2}{*}{ DIDep } & & & -0.00461 & & & & & & $-0.0939 * * *$ & & & & & & $-0.0615^{* * * *}$ & & & \\
\hline & & & $(-0.65)$ & & & & & & $(-3.68)$ & & & & & & $(-2.99)$ & & & \\
\hline \multirow[t]{2}{*}{ DIFund } & & & & -0.00846 & & & & & & -0.0318 & & & & & & -0.0817 & & \\
\hline & & & & $(-0.63)$ & & & & & & $(-1.15)$ & & & & & & $(-1.12)$ & & \\
\hline \multirow[t]{2}{*}{ DIM emo } & & & & & -0.00293 & & & & & & $-0.0548 * * *$ & & & & & & $-0.0372 * * *$ & \\
\hline & & & & & $(-0.67)$ & & & & & & $(-5.11)$ & & & & & & $(-3.66)$ & \\
\hline \multirow[t]{2}{*}{ DIIS } & & & & & & -0.00947 & & & & & & $-0.106^{* * *}$ & & & & & & $-0.0773 * * *$ \\
\hline & & & & & & $(-0.71)$ & & & & & & $(-2.89)$ & & & & & & $(-2.80)$ \\
\hline \multirow[t]{2}{*}{ PBV } & 0.0250 & 0.0251 & 0.0223 & 0.0353 & 0.0267 & 0.0341 & -0.0464 & -0.0377 & -0.0930 & -0.0163 & -0.000745 & 0.0795 & -0.0580 & -0.0593 & -0.0936 & 0.123 & -0.0315 & 0.0342 \\
\hline & $(0.79)$ & $(0.78)$ & $(0.71)$ & $(0.91)$ & $(0.82)$ & $(0.96)$ & $(-0.75)$ & $(-0.72)$ & $(-1.11)$ & $(-0.25)$ & $(-0.01)$ & $(0.92)$ & $(-1.05)$ & $(-1.22)$ & $(-1.35)$ & $(0.72)$ & $(-0.62)$ & $(0.50)$ \\
\hline \multirow[t]{2}{*}{ Size } & 0.0230 & 0.0190 & 0.0305 & 0.0289 & 0.0255 & 0.0337 & 0.0688 & 0.00131 & 0.191 & 0.0324 & 0.0742 & 0.103 & 0.0279 & -0.0230 & 0.0988 & 0.00596 & 0.0258 & 0.0512 \\
\hline & $(0.60)$ & $(0.50)$ & $(0.71)$ & $(0.71)$ & $(0.64)$ & $(0.83)$ & $(0.96)$ & $(0.02)$ & (1.49) & $(0.38)$ & $(1.03)$ & $(0.84)$ & $(0.47)$ & $(-0.45)$ & $(0.89)$ & $(0.05)$ & $(0.43)$ & $(0.58)$ \\
\hline \multirow[t]{2}{*}{ Tier1 } & -0.0133 & -0.0126 & -0.0151 & -0.0199 & -0.0117 & -0.0108 & 0.00319 & 0.0208 & -0.0347 & -0.0176 & 0.0335 & 0.0268 & -0.0106 & 0.00286 & -0.0351 & -0.0751 & 0.00942 & 0.00686 \\
\hline & $(-1.45)$ & $(-1.39)$ & $(-1.54)$ & $(-1.40)$ & $(-1.27)$ & $(-1.16)$ & $(0.13)$ & $(0.99)$ & $(-0.96)$ & $(-0.61)$ & (1.53) & $(1.01)$ & $(-0.51)$ & $(0.16)$ & $(-1.24)$ & $(-1.20)$ & $(0.49)$ & $(0.29)$ \\
\hline \multirow[t]{2}{*}{ Growth } & $0.0250^{* *}$ & $0.0261^{* * *}$ & $0.0260^{* * *}$ & $0.0327^{* *}$ & $0.0250^{* *}$ & $0.0263^{* * *}$ & $0.0541 *$ & $0.0942^{* * *}$ & $0.0942^{* * *}$ & $0.127^{* * *}$ & $0.0706^{* * *}$ & $0.0892 * * *$ & $0.0759^{* *}$ & $0.102^{* * *}$ & $0.0996^{* * *}$ & $0.156^{* * *}$ & $0.0879 * * *$ & $0.0991 * * *$ \\
\hline & $(2.37)$ & $(2.72)$ & $(2.69)$ & $(2.48)$ & $(2.48)$ & $(2.70)$ & $(1.78)$ & $(3.49)$ & $(2.74)$ & $(3.88)$ & $(2.63)$ & $(2.82)$ & $(2.45)$ & (3.60) & $(3.07)$ & $(2.43)$ & (3.10) & (3.16) \\
\hline \multirow[t]{2}{*}{ Interest } & 0.00725 & 0.00852 & 0.00475 & 0.00432 & 0.00891 & 0.00904 & $-0.0605^{*}$ & -0.0289 & $-0.117^{* * *}$ & $-0.0734 * * *$ & -0.0342 & -0.0516 & -0.0257 & -0.00172 & $-0.0615^{* *}$ & -0.0475 & -0.00615 & -0.0175 \\
\hline & $(0.68)$ & $(0.78)$ & $(0.42)$ & $(0.34)$ & $(0.79)$ & $(0.77)$ & $(-1.87)$ & $(-1.19)$ & $(-3.11)$ & $(-2.60)$ & $(-1.19)$ & $(-1.18)$ & $(-1.01)$ & $(-0.08)$ & $(-1.99)$ & $(-1.12)$ & $(-0.24)$ & $(-0.51)$ \\
\hline \multirow[t]{2}{*}{ Inflation } & 0.00303 & 0.00400 & 0.00113 & 0.00521 & 0.00590 & 0.00859 & -0.0102 & 0.00291 & $-0.0573 *$ & -0.0202 & 0.0374 & 0.0567 & 0.0133 & 0.0290 & -0.0130 & 0.0701 & $0.0518^{*}$ & $0.0699 *$ \\
\hline & $(0.30)$ & $(0.38)$ & $(0.11)$ & $(0.44)$ & $(0.51)$ & $(0.65)$ & $(-0.39)$ & $(0.13)$ & $(-1.84)$ & $(-0.80)$ & $(1.26)$ & $(1.15)$ & $(0.57)$ & $(1.35)$ & $(-0.49)$ & $(0.95)$ & $(1.91)$ & $(1.76)$ \\
\hline \multirow[t]{2}{*}{ Covdep } & $0.0416 *$ & 0.0386 & 0.0408 & $0.0501 *$ & 0.0334 & $0.0434 *$ & $0.226^{* * *}$ & $0.156^{* *}$ & $0.207^{* *}$ & $0.244^{* * *}$ & 0.0650 & $0.227^{* * *}$ & $0.221 * * *$ & $0.175^{* *}$ & $0.207^{* * *}$ & $0.284 * * *$ & 0.112 & $0.223^{* * *}$ \\
\hline & (1.68) & (1.44) & (1.60) & (1.65) & (1.10) & (1.66) & (3.66) & $(2.56)$ & (2.54) & (3.60) & $(0.93)$ & (2.63) & (3.39) & $(2.52)$ & $(2.80)$ & (2.65) & (1.49) & (2.69) \\
\hline $\mathrm{N}$ & 1023 & 1025 & 1023 & 1023 & 1023 & 1023 & 963 & 1027 & 1027 & 1025 & 1027 & 1027 & 1008 & 1008 & 1008 & 953 & 1008 & 1008 \\
\hline F-stat & $19.00^{* * *}$ & $20.33^{* * *}$ & $18.52^{* * *}$ & $14.27^{* * *}$ & $17.61 * * *$ & $16.76^{* * *}$ & $7.53^{* * * *}$ & $7.75^{* * *}$ & $7.58 * * *$ & $4.30^{* * *}$ & $9.46^{* * *}$ & $6.79^{* * * *}$ & $7.97 * * *$ & $7.98 * * *$ & $7.17^{* * * *}$ & $2.12^{* * *}$ & $8.29 * * *$ & $6.51^{* * *}$ \\
\hline Underid. tes & $35.453^{* * *}$ & $71.091^{* * *}$ & $17.232^{* * *}$ & 1.172 & $29.831^{* * *}$ & $9.236^{* *}$ & $33.068^{* * *}$ & $62.103^{* * *}$ & $15.326^{* * *}$ & 1.429 & $30.174 * * *$ & $11.899 * * *$ & $30.982^{* * *}$ & $68.428^{* * *}$ & $15.443 * * *$ & 2.452 & $28.433 * * *$ & $11.584^{* * * *}$ \\
\hline Hansen J sta & 3.417 & 3.257 & 2.984 & 1.787 & 2.331 & 1.659 & 1.823 & $8.979^{* * *}$ & 0.055 & $33.529^{* * *}$ & 0.016 & 0.593 & 0.061 & 3.135 & 0.064 & 3.659 & 0.059 & 0.005 \\
\hline Endog.test, & 0.167 & 0.815 & 0.602 & 0.468 & 1.976 & 1.201 & $30.030^{* * *}$ & $24.498 * * *$ & $39.023 * * *$ & 2.578 & $33.147 * * *$ & $34.533 * * *$ & $14.488^{* * *}$ & $8.341^{* * *}$ & $16.122 * * *$ & $4.830^{* * *}$ & $12.729 * * *$ & $14.330 * * *$ \\
\hline
\end{tabular}

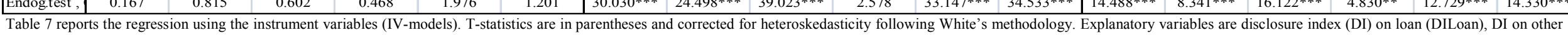
earning assests (DIEA), DI on deposits (DIDep), Dl on other funding (DIFund), DI on memo lines (DIMemo), DI on income statements items, the control variables (PBV, Size, tier-1 capital ratio, coverage of insurance deposits, GDP growth, interest rate, assets, SDROA = the standard deviation of ROA based on two previous years data, SDROE = standard deviation of return on equity. The values of Z-score, Z-score 1 and Z-score 2 are in natural logarithm. Independent variables are in decimals except described otherwise. Superscripts $* * *, * *$, and $*$ denotes statistical significant at the $0.01,0.05$ and 0.10 levels respectively. 
Table A.1 Robustness test: The impact of disclosure (DI) on bank risk using the fixed effect models

\begin{tabular}{|c|c|c|c|c|c|c|c|c|c|c|c|c|c|c|c|c|c|c|c|c|c|c|c|c|}
\hline \multirow{2}{*}{\begin{tabular}{|l} 
Dep. Var \\
Model \\
\end{tabular}} & \multicolumn{4}{|c|}{ Z-score } & \multicolumn{4}{|c|}{ Z-score 1} & \multicolumn{4}{|c|}{ Z-score 2} & \multicolumn{4}{|c|}{ NPL to Cap } & \multicolumn{4}{|c|}{ SDROA } & \multicolumn{4}{|c|}{ SDROE } \\
\hline & (1) & (2) & (3) & (4) & (1) & (2) & (3) & (4) & (1) & (2) & (3) & (4) & (1) & (2) & (3) & (4) & (1) & (2) & (3) & (4) & (1) & (2) & (3) & (4) \\
\hline \multirow[t]{2}{*}{ DI } & $0.0214^{* * *}$ & $0.0218^{* * *}$ & $0.0220^{* * * *}$ & $0.0211 * * *$ & $0.0133^{* *}$ & $0.0135^{* * *}$ & $0.0138^{* * * *}$ & $0.0130^{* *}$ & $0.0218^{* * *}$ & $0.0221 * * *$ & $0.0224 * * *$ & $0.0215^{* * *}$ & 0.00106 & 0.00115 & 0.00105 & $0.0130^{* *}$ & $-0.0174 * * *$ & $-0.0177^{* * *}$ & $-0.0181 * * *$ & * $-0.0172 * * *$ & $-0.00786^{*}$ & $-0.00793 *$ & $-0.00837^{*}$ & $-0.00814 *$ \\
\hline & $(4.47)$ & $(4.59)$ & $(4.54)$ & $(4.36)$ & $(2.51)$ & $(2.62)$ & $(2.63)$ & $(2.48)$ & $(4.73)$ & $(4.84)$ & $(4.80)$ & $(4.63)$ & $(0.34)$ & $(0.37)$ & $(0.34)$ & $(2.48)$ & $(-4.09)$ & $(-4.21)$ & $(-4.24)$ & $(-4.02)$ & $(-1.74)$ & $(-1.73)$ & $(-1.82)$ & $(-1.77)$ \\
\hline \multirow[t]{2}{*}{ Insiders } & 0.00576 & 0.00553 & 0.00551 & 0.00499 & $0.0260^{* * *}$ & $* 0.0262^{* * *}$ & $0.0258^{* * *}$ & $0.0259 * * *$ & 0.00583 & 0.00566 & 0.00555 & 0.00519 & 0.00491 & 0.00481 & 0.00477 & $0.0259^{* * *}$ & -0.00853 & -0.00841 & -0.00820 & -0.00799 & -0.00608 & -0.00596 & -0.00585 & -0.00552 \\
\hline & $(0.71)$ & $(0.68)$ & $(0.68)$ & $(0.64)$ & $(3.38)$ & $(3.37)$ & $(3.36)$ & $(3.43)$ & $(0.74)$ & $(0.71)$ & $(0.71)$ & $(0.69)$ & $(0.84)$ & $(0.82)$ & $(0.81)$ & $(3.43)$ & $(-1.10)$ & $(-1.08)$ & $(-1.06)$ & $(-1.08)$ & $(-1.48)$ & $(-1.42)$ & $(-1.43)$ & $(-1.36)$ \\
\hline \multirow[t]{2}{*}{ Inst } & 0.000372 & & & & -0.00197 & & & & -0.000104 & & & & 0.000116 & & & & 0.000634 & & & & 0.00116 & & & \\
\hline & $(0.14)$ & & & & $(-0.79)$ & & & & $(-0.04)$ & & & & $(0.10)$ & & & & $(0.27)$ & & & & $(0.37)$ & & & \\
\hline \multirow[t]{2}{*}{ Gown } & & $-0.0180^{* * *}$ & & & & $-0.0168^{* * * *}$ & & & & $-0.0173^{* *}$ & & & & $-0.00887 * * * *$ & & & & $0.0173 * * *$ & & & & 0.00910 & & \\
\hline & & $(-2.73)$ & & & & $(-2.73)$ & & & & $(-2.59)$ & & & & $(-3.27)$ & & & & $(2.72)$ & & & & $(1.04)$ & & \\
\hline \multirow[t]{2}{*}{ Block } & & & -0.00227 & & & & $-0.00519^{*}$ & & & & -0.00310 & & & & -0.000808 & & & & 0.00427 & & & & 0.00331 & \\
\hline & & & $(-0.82)$ & & & & $(-1.79)$ & & & & $(-1.14)$ & & & & $(-0.74)$ & & & & $(1.61)$ & & & & $(0.97)$ & \\
\hline \multirow[t]{2}{*}{$\mathrm{HHI}$} & & & & 0.000695 & & & & -0.00204 & & & & -0.0000456 & & & & -0.00204 & & & & 0.00127 & & & & -0.00217 \\
\hline & & & & $(0.15)$ & & & & $(-0.41)$ & & & & $(-0.01)$ & & & & $(-0.41)$ & & & & $(0.29)$ & & & & $(-0.47)$ \\
\hline \multirow[t]{2}{*}{ PBV } & 0.0371 & 0.0223 & 0.0350 & 0.0375 & $0.142^{*}$ & $0.126^{*}$ & $0.134^{*}$ & $0.136^{*}$ & 0.0416 & 0.0268 & 0.0384 & 0.0408 & 0.0203 & 0.00849 & 0.0200 & $0.136^{*}$ & -0.0583 & -0.0419 & -0.0536 & -0.0559 & -0.0494 & -0.0468 & -0.0449 & -0.0527 \\
\hline & $(0.58)$ & $(0.36)$ & $(0.55)$ & $(0.58)$ & (1.94) & (1.79) & $(1.83)$ & (1.83) & $(0.68)$ & $(0.45)$ & $(0.62)$ & $(0.65)$ & $(0.51)$ & $(0.22)$ & $(0.51)$ & $(1.83)$ & $(-1.02)$ & $(-0.77)$ & $(-0.94)$ & $(-0.97)$ & $(-0.91)$ & $(-0.87)$ & $(-0.84)$ & $(-0.99)$ \\
\hline \multirow[t]{2}{*}{ Size } & -0.00850 & -0.00541 & -0.00870 & -0.00626 & 0.0397 & 0.0397 & 0.0383 & 0.0403 & -0.00725 & -0.00463 & -0.00794 & -0.00550 & 0.0324 & 0.0337 & 0.0324 & 0.0403 & -0.00625 & -0.00847 & -0.00499 & -0.00793 & -0.0448 & -0.0455 & -0.0432 & -0.0496 \\
\hline & $(-0.15)$ & $(-0.10)$ & $(-0.15)$ & $(-0.11)$ & $(0.51)$ & $(0.51)$ & $(0.50)$ & $(0.52)$ & $(-0.13)$ & $(-0.08)$ & $(-0.14)$ & $(-0.10)$ & $(0.80)$ & $(0.83)$ & $(0.80)$ & $(0.52)$ & $(-0.11)$ & $(-0.14)$ & $(-0.08)$ & $(-0.13)$ & $(-1.05)$ & $(-1.06)$ & $(-1.01)$ & $(-1.15)$ \\
\hline \multirow[t]{2}{*}{ Tier1 } & 381 & 0.0380 & 0387 & 0.0377 & -0.000152 & 0.000142 & -0.000196 & 0.00158 & 0.0334 & 0.0334 & 0.0340 & 0.0333 & -0.00741 & -0.00796 & -0.00763 & 0.00158 & 0.00787 & 0.00780 & 0.00709 & 0.00759 & -0.0149 & -0.0151 & -0.0157 & -0.0129 \\
\hline & $(1.27)$ & $(1.29)$ & $(1.29)$ & $(1.26)$ & $(-0.00)$ & $(0.00)$ & $(-0.01)$ & $(0.05)$ & $(1.14)$ & $(1.16)$ & $(1.17)$ & $(1.14)$ & $(-0.74)$ & $(-0.78)$ & $(-0.76)$ & $(0.05)$ & $(0.30)$ & $(0.30)$ & $(0.27)$ & $(0.29)$ & $(-0.66)$ & $(-0.68)$ & $(-0.70)$ & $(-0.57)$ \\
\hline \multirow[t]{2}{*}{ Growth } & $-0.112 * * *$ & $-0.111^{* * * *}$ & $-0.113^{* * *}$ & $-0.111 * * *$ & $-0.110^{* * *}$ & $-0.110^{* * *}$ & $-0.110^{* * *}$ & $-0.108^{* * *}$ & $-0.106 * * *$ & $-0.106^{* * *}$ & $-0.108^{* * *}$ & $-0.105^{* * *}$ & $0.0310^{* * *}$ & $0.0330^{* * *}$ & $0.0314^{* * *}$ & * $-0.108^{* * *}$ & $0.0979 * * *$ & $0.0967 * * *$ & $0.0989^{* * *}$ & $0.0957^{* * *}$ & $0.100^{* * *}$ & $0.100^{* * *}$ & $0.101^{* * *}$ & $0.100^{* * *}$ \\
\hline & $(-3.65)$ & $(-3.61)$ & $(-3.70)$ & $(-3.57)$ & $(-3.29)$ & $(-3.27)$ & $(-3.30)$ & $(-3.18)$ & $(-3.59)$ & $(-3.54)$ & $(-3.63)$ & $(-3.49)$ & $(3.06)$ & $(3.31)$ & $(3.15)$ & $(-3.18)$ & (3.38) & $(3.33)$ & $(3.42)$ & $(3.27)$ & $(2.91)$ & $(2.88)$ & $(2.94)$ & $(2.88)$ \\
\hline \multirow[t]{2}{*}{ Interest } & $0.0540^{* *}$ & $0.0598^{* * *}$ & $0.0543 * *$ & $0.0519^{* *}$ & $0.0739^{* * *}$ & ${ }^{*} 0.0796^{* * *}$ & $0.0745^{* * *}$ & $0.0739 * * *$ & $0.0521 * *$ & $0.0578^{* * *}$ & $0.0525^{* *}$ & $0.0502^{* *}$ & 0.0140 & 0.0167 & 0.0139 & $0.0739^{* * *}$ & $-0.0537^{* * *}$ & $-0.0593^{* * *}$ & $-0.0542 * * *$ & *-0.0519** & -0.0281 & -0.0309 & -0.0285 & -0.0289 \\
\hline & $(2.44)$ & $(2.77)$ & $(2.46)$ & $(2.33)$ & $(2.92)$ & $(3.31)$ & $(2.98)$ & $(2.91)$ & $(2.45)$ & $(2.79)$ & $(2.48)$ & $(2.34)$ & (1.36) & (1.65) & (1.36) & (2.91) & $(-2.66)$ & $(-3.04)$ & $(-2.72)$ & $(-2.56)$ & $(-1.36)$ & $(-1.53)$ & $(-1.38)$ & $(-1.39)$ \\
\hline \multirow[t]{2}{*}{ Inflation } & 0.0123 & 0.0140 & 0.0113 & 0.0109 & 0.0237 & 0.0259 & 0.0214 & 0.0220 & 0.0104 & 0.0121 & 0.00906 & 0.00863 & 0.00324 & 0.00303 & 0.00274 & 0.0220 & -0.0179 & -0.0195 & -0.0160 & -0.0153 & 0.0118 & 0.00941 & 0.0130 & 0.00799 \\
\hline & $(0.58)$ & $(0.67)$ & $(0.53)$ & $(0.49)$ & $(0.92)$ & $(1.03)$ & $(0.84)$ & $(0.82)$ & $(0.50)$ & $(0.59)$ & $(0.44)$ & $(0.40)$ & $(0.28)$ & $(0.26)$ & $(0.23)$ & $(0.82)$ & $(-0.84)$ & $(-0.94)$ & $(-0.76)$ & $(-0.69)$ & $(0.53)$ & $(0.42)$ & $(0.58)$ & $(0.37)$ \\
\hline \multirow[t]{2}{*}{ Covdep } & $-0.226 * * *$ & $-0.208^{* * * *}$ & $-0.224 * * *$ & $-0.227 * * *$ & $-0.241 * * *$ & $-0.222 * * *$ & $-0.235 * * *$ & $-0.241^{* * *}$ & $-0.216^{* * *}$ & $-0.199 * * *$ & $-0.214^{* * *}$ & $-0.217^{* * *}$ & 0.0330 & 0.0428 & 0.0343 & $-0.241^{* * * *}$ & $0.195^{* * * *}$ & $0.178^{* * *}$ & $0.192 * * *$ & $0.194 * * *$ & $0.217^{* * *}$ & $0.207 * * *$ & $0.214^{* * *}$ & $0.217^{* * *}$ \\
\hline & & $(-3.53)$ & & & & & $(-3.34)$ & $(-3.37)$ & $(-3.58)$ & $(-3.44)$ & $(-3.55)$ & $(-3.57)$ & & & & $(-3.37)$ & $(3.29)$ & & & & & $(3.07)$ & & $(3.20)$ \\
\hline Intercept & $2.759^{* * * *}$ & $2.841^{* * * *}$ & $2.817^{* * * *}$ & $2.743^{* * * *}$ & & 0.652 & 0.707 & 0. & $2.648 * * *$ & $2.716^{* * * *}$ & $2.714^{* * * *}$ & $2.627^{* * * *}$ & $3.579^{* * *}$ & $3.631^{* * * *}$ & $3.611^{* * * *}$ & 0.554 & -1.234 & $-1.289^{*}$ & $-1.316^{*}$ & -1.205 & $1.807 * * *$ & $1.812 * * *$ & $1.761 * * *$ & $1.889^{* * *}$ \\
\hline & $(3.64)$ & $(3.85)$ & $(3.74)$ & $(3.70)$ & $(0.69)$ & $(0.73)$ & $(0.79)$ & $(0.62)$ & (3.54) & $(3.73)$ & $(3.67)$ & $(3.60)$ & $(6.93)$ & $(6.98)$ & $(6.93)$ & $(0.62)$ & $(-1.60)$ & $(-1.71)$ & $(-1.73)$ & $(-1.59)$ & $(2.67)$ & $(2.77)$ & $(2.62)$ & $(2.84)$ \\
\hline No. obs, & 968 & 973 & 972 & 965 & 891 & 895 & 894 & 889 & 968 & 973 & 972 & 965 & 965 & 970 & & 889 & 968 & 973 & 972 & & 955 & 960 & 959 & 953 \\
\hline R-square & 0.143 & 0.153 & 0.147 & 0.138 & 0.141 & 0.148 & 0.146 & 0.138 & 0.146 & 0.156 & 0.151 & 0.142 & 0.197 & 0.203 & & 0.138 & 0.125 & 0.135 & 0.130 & 0.121 & 0.125 & 0.128 & 0.128 & 0.116 \\
\hline F-stat. & $6.319 * * *$ & $6.660^{* * *}$ & $6.463 * * *$ & $6.001 * * *$ & $6.264 * * *$ & $6.827^{* * *}$ & $6.638^{* * *}$ & $6.094 * * *$ & $6.674 * * *$ & $7.032^{* * *}$ & $6.838^{* * *}$ & $6.315^{* * *}$ & $10.11 * * *$ & $11.64 * * *$ & $10.08^{* * *}$ & $6.094 * * *$ & $5.994 * * *$ & $6.336 * * *$ & $6.191 * * *$ & $5.609 * * *$ & $5.739 * * *$ & $5.959 * * *$ & $5.948^{* * *}$ & $5.348^{*}$ \\
\hline
\end{tabular}

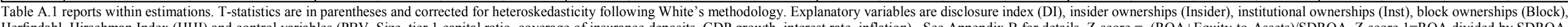

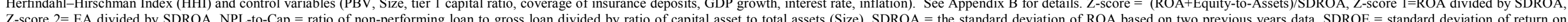

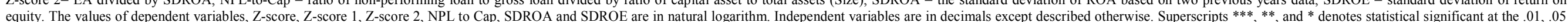
and 10 levels respectively. 
Table A.2 Robustness test: The impact of disclosure (DI) and the interaction terms on bank risk using the fixed effect models

\begin{tabular}{|c|c|c|c|c|c|c|c|c|c|c|c|c|c|c|c|}
\hline \multirow{2}{*}{\begin{tabular}{|l} 
Dep. Var \\
Model
\end{tabular}} & \multicolumn{5}{|c|}{ Zscore } & \multicolumn{5}{|c|}{ Z-score 1} & \multicolumn{5}{|c|}{ Z-score 2} \\
\hline & (1) & (2) & (3) & (4) & (5) & (1) & (2) & (3) & (4) & (5) & (1) & (2) & (3) & (4) & $(5)$ \\
\hline \multirow[t]{2}{*}{ DI } & $0.0202^{* * *}$ & $0.0193^{* * *}$ & $0.0228^{* * *}$ & $0.0217^{* *}$ & $0.0184^{* *}$ & $0.0120^{* *}$ & $0.0150^{* *}$ & $0.0121^{*}$ & 0.0129 & 0.0133 & $0.0204 * * *$ & $0.0202 * * *$ & $0.0229 * * *$ & $0.0215^{* * *}$ & $0.0190^{* * *}$ \\
\hline & $(4.14)$ & $(2.94)$ & $(4.25)$ & $(2.53)$ & $(2.52)$ & $(2.31)$ & $(2.38)$ & $(1.89)$ & $(1.22)$ & $(1.37)$ & $(4.34)$ & $(3.24)$ & $(4.44)$ & $(2.63)$ & $(2.82)$ \\
\hline \multirow[t]{2}{*}{ Insiders } & 0.0285 & & & & & -0.00804 & & & & & 0.0235 & & & & \\
\hline & $(0.59)$ & & & & & $(-0.14)$ & & & & & $(0.52)$ & & & & \\
\hline \multirow[t]{2}{*}{ DIxInsiders } & -0.000233 & & & & & 0.000462 & & & & & -0.000168 & & & & \\
\hline & $(-0.41)$ & & & & & $(0.66)$ & & & & & $(-0.32)$ & & & & \\
\hline \multirow[t]{2}{*}{ Inst } & & -0.00339 & & & & & 0.00138 & & & & & -0.00296 & & & \\
\hline & & $(-0.38)$ & & & & & $(0.18)$ & & & & & $(-0.36)$ & & & \\
\hline \multirow[t]{2}{*}{ DIXInst } & & 0.0000528 & & & & & -0.0000489 & & & & & 0.0000400 & & & \\
\hline & & $(0.47)$ & & & & & $(-0.48)$ & & & & & $(0.37)$ & & & \\
\hline \multirow[t]{2}{*}{ Gown } & & & -0.0142 & & & & & $-0.0213^{*}$ & & & & & -0.0142 & & \\
\hline & & & $(-1.16)$ & & & & & $(-1.71)$ & & & & & $(-1.18)$ & & \\
\hline \multirow[t]{2}{*}{ DIxGown } & & & -0.0000537 & & & & & 0.0000636 & & & & & -0.0000437 & & \\
\hline & & & $(-0.37)$ & & & & & $(0.41)$ & & & & & $(-0.31)$ & & \\
\hline \multirow[t]{2}{*}{ Block } & & & & -0.00263 & & & & & -0.00627 & & & & & -0.00432 & \\
\hline & & & & $(-0.28)$ & & & & & $(-0.67)$ & & & & & $(-0.49)$ & \\
\hline \multirow[t]{2}{*}{ DIxBlock } & & & & 0.00000489 & & & & & 0.0000139 & & & & & 0.0000174 & \\
\hline & & & & $(0.04)$ & & & & & $(0.10)$ & & & & & $(0.14)$ & \\
\hline \multirow[t]{2}{*}{ HHI } & & & & & -0.00608 & & & & & -0.00100 & & & & & -0.00625 \\
\hline & & & & & $(-0.48)$ & & & & & $(-0.07)$ & & & & & $(-0.52)$ \\
\hline \multirow[t]{2}{*}{ DIxHHI } & & & & & 0.000102 & & & & & -0.0000147 & & & & & 0.000094 \\
\hline & & & & & $(0.56)$ & & & & & $(-0.07)$ & & & & & $(0.55)$ \\
\hline \multirow[t]{2}{*}{ PBV } & 0.0415 & 0.0385 & 0.0225 & 0.0347 & 0.0363 & $0.150^{* *}$ & $0.139 *$ & $0.123^{*}$ & $0.133^{*}$ & $0.135^{*}$ & 0.0437 & 0.0426 & 0.0269 & 0.0384 & 0.0396 \\
\hline & $(0.66)$ & $(0.60)$ & $(0.36)$ & $(0.54)$ & $(0.56)$ & $(2.11)$ & (1.88) & $(1.74)$ & (1.79) & $(1.80)$ & $(0.72)$ & $(0.69)$ & $(0.45)$ & $(0.62)$ & $(0.63)$ \\
\hline \multirow[t]{2}{*}{ TA } & -0.0158 & -0.00827 & -0.00352 & -0.00896 & -0.00975 & 0.0336 & 0.0392 & 0.0372 & 0.0370 & 0.0400 & -0.0148 & -0.00706 & -0.00308 & -0.00896 & -0.00870 \\
\hline & $(-0.28)$ & $(-0.15)$ & $(-0.06)$ & $(-0.16)$ & $(-0.17)$ & $(0.44)$ & $(0.51)$ & $(0.48)$ & $(0.47)$ & $(0.51)$ & $(-0.27)$ & $(-0.13)$ & $(-0.06)$ & $(-0.16)$ & $(-0.16)$ \\
\hline Tierl & 0.0431 & 0.0378 & 0.0372 & 0.0384 & 0.0375 & 0.00180 & -0.000882 & -0.0000949 & -0.000953 & 0.000816 & 0.0381 & 0.0331 & 0.0327 & 0.0338 & 0.0331 \\
\hline & $(1.43)$ & $(1.26)$ & $(1.26)$ & $(1.28)$ & $(1.25)$ & $(0.06)$ & $(-0.03)$ & $(-0.00)$ & $(-0.03)$ & $(0.03)$ & $(1.30)$ & $(1.13)$ & $(1.13)$ & $(1.16)$ & (1.13) \\
\hline Growth & $-0.113 * * *$ & $-0.112^{* * *}$ & $-0.112 * * *$ & $-0.114 * * *$ & $-0.111 * * *$ & $-0.113 * * *$ & $-0.113^{* * *}$ & $-0.112 * * *$ & $-0.113^{* * *}$ & $-0.110^{* * *}$ & $-0.108^{* * * *}$ & $-0.107^{* * *}$ & $-0.106 * * *$ & $-0.108 * * *$ & $-0.106 * * *$ \\
\hline & $(-3.77)$ & $(-3.69)$ & $(-3.65)$ & $(-3.73)$ & $(-3.62)$ & $(-3.43)$ & $(-3.35)$ & $(-3.31)$ & $(-3.35)$ & $(-3.24)$ & $(-3.69)$ & $(-3.62)$ & $(-3.58)$ & $(-3.66)$ & $(-3.54)$ \\
\hline Interest & $0.0569^{* * *}$ & $0.0540^{* *}$ & $0.0598^{* * *}$ & $0.0543 * *$ & $0.0516^{* *}$ & $0.0754^{* * *}$ & $0.0728^{* * *}$ & $0.0787 * * *$ & $0.0737^{* * *}$ & $0.0730^{* * *}$ & $0.0556^{* * *}$ & $0.0522^{* *}$ & $0.0578^{* * *}$ & $0.0525^{* *}$ & $0.0499 * *$ \\
\hline & $(2.76)$ & $(2.45)$ & $(2.78)$ & $(2.45)$ & $(2.33)$ & (3.19) & $(2.87)$ & $(3.25)$ & $(2.94)$ & $(2.86)$ & $(2.81)$ & $(2.45)$ & $(2.79)$ & $(2.47)$ & $(2.34)$ \\
\hline Inflation & 0.0172 & 0.0135 & 0.0149 & 0.0116 & 0.0102 & 0.0279 & 0.0235 & 0.0259 & 0.0222 & 0.0229 & 0.0159 & 0.0114 & 0.0129 & 0.00949 & 0.00802 \\
\hline & $(0.84)$ & $(0.62)$ & $(0.70)$ & $(0.54)$ & $(0.46)$ & $(1.13)$ & $(0.92)$ & $(1.03)$ & $(0.88)$ & $(0.86)$ & $(0.79)$ & $(0.54)$ & $(0.62)$ & $(0.46)$ & $(0.37)$ \\
\hline Covdep & $-0.238 * * *$ & $-0.225^{* * *}$ & $-0.207 * * *$ & $-0.224^{* * *}$ & $-0.225^{* * *}$ & $-0.251 * * *$ & $-0.242 * * *$ & $-0.224 * * *$ & $-0.235^{* * * *}$ & $-0.242 * * *$ & $-0.228 * * *$ & $-0.216 * * *$ & $-0.199 * * *$ & $-0.214 * * *$ & $-0.215^{* * *}$ \\
\hline & $(-3.91)$ & $(-3.64)$ & $(-3.53)$ & $(-3.64)$ & $(-3.62)$ & $(-3.56)$ & $(-3.39)$ & $(-3.32)$ & $(-3.34)$ & $(-3.36)$ & $(-3.82)$ & $(-3.56)$ & $(-3.44)$ & $(-3.54)$ & $(-3.53)$ \\
\hline Intercept & $2.812 * * *$ & $2.911 * * *$ & $2.765^{* * *}$ & $2.849 * * *$ & $2.976^{* * *}$ & 0.621 & 0.555 & 0.820 & 0.826 & 0.579 & $2.697 * * *$ & $2.766^{* * *}$ & $2.656^{* * * *}$ & $2.796 * * *$ & $2.843 * * *$ \\
\hline & $(3.71)$ & $(3.45)$ & $(3.65)$ & $(3.09)$ & $(3.65)$ & $(0.70)$ & $(0.59)$ & $(0.88)$ & $(0.76)$ & $(0.55)$ & $(3.61)$ & $(3.34)$ & $(3.55)$ & $(3.10)$ & $(3.55)$ \\
\hline No. obs, & 1028 & 969 & 974 & 973 & 966 & 942 & 892 & 896 & 895 & 890 & 1028 & 969 & 974 & 973 & 966 \\
\hline R-square & 0.150 & 0.143 & 0.153 & 0.147 & 0.138 & 0.148 & 0.138 & 0.145 & 0.143 & 0.136 & 0.153 & 0.146 & 0.156 & 0.151 & 0.142 \\
\hline F-stat. & $8.192 * * *$ & $6.346 * * *$ & $6.758 * * *$ & $6.422 * * *$ & $5.944 * * *$ & $7.321 * * *$ & $5.453^{* * *}$ & $6.045^{* * *}$ & $6.241 * * *$ & $5.351^{* * *}$ & $8.620 * * *$ & $6.700^{* * *}$ & $7.117 * * *$ & $6.819 * * *$ & $6.253^{* * *}$ \\
\hline Significance tes & & & & & & & & & & & & & & & \\
\hline DI+DIxIown & $17.43^{* * *}$ & & & & & $6.05 * *$ & & & & & $19.39 * * *$ & & & & \\
\hline DI+DIxInst & & $8.93 * * *$ & & & & & $5.73 * *$ & & & & & $10.78 * * *$ & & & \\
\hline DI+DIxGown & & & $18.42 * * *$ & & & & & $3.71^{*}$ & & & & & $20.12 * * *$ & & \\
\hline DI+DIxBlock & & & & $6.57^{* *}$ & & & & & 1.53 & & & & & $7.08 * * *$ & \\
\hline DI+DIxHHI & & & & & $6.66 * * *$ & & & & & 1.95 & & & & & $8.35 * * *$ \\
\hline
\end{tabular}

Table A.2 reports within estimations. T-statistics are in parentheses and corrected for heteroskedasticity following White's methodology. Explanatory variables are disclosure index (DI), insider ownerships (Insiders), institutional ownerships (Inst), block ownerships (Block), Herfindahl-Hirschman Index (HHI) and control variables. We also include interaction terms between disclosure and insider ownerships (DIxIown), institution ownerships (DIxinst), governerment ownerships (DIxgown), block ownerships (DIxblock), ownership concentration (DIxHHi) and the control variables (PBV, Size, Tier 1 capital ratio, coverage of insurance deposits, GDP growth, interest rate, inflation). Z-score $=($ ROA+Equity-to-Assets $) /$ SDROA, Z-score 1=ROA divided by SDROA, Z-score 2= EA divided by SDROA. The values of dependent variables, Z-score, Z-score 1, $Z$-score 2 are in natural logarithm. Independent variables are in decimals except described otherwise. Significance test is the test of the null hypothesis that the sum of the coefficients of disclosure and the interaction term do not have joint impacts on risk. Superscripts ***,**, and * denotes statistical significant at the .01 , .05 and .10 levels respectively. 
Table A.2 Robustness test: The impact of disclosure (DI) and the interaction terms on bank risk using the fixed effect models (cont'd)

\begin{tabular}{|c|c|c|c|c|c|c|c|c|c|c|c|c|c|c|c|}
\hline \multirow{2}{*}{\begin{tabular}{|l|} 
Dep. Var \\
Model
\end{tabular}} & \multicolumn{5}{|c|}{ NPL to Cap } & \multicolumn{5}{|c|}{ SDROA } & \multicolumn{5}{|c|}{ SDROE } \\
\hline & (1) & (2) & (3) & (4) & (5) & (1) & (2) & (3) & (4) & (5) & (1) & (2) & (3) & (4) & (5) \\
\hline \multirow[t]{2}{*}{ DI } & 0.0000387 & -0.000846 & 0.000722 & -0.00505 & -0.00280 & $-0.0158^{* * * *}$ & $-0.0186^{* * *}$ & $-0.0168 * * *$ & $-0.0151 * *$ & $-0.0149 * *$ & -0.00648 & -0.00746 & -0.00561 & -0.00194 & -0.00157 \\
\hline & $(0.01)$ & $(-0.26)$ & $(0.18)$ & $(-1.18)$ & $(-0.65)$ & $(-3.57)$ & $(-2.83)$ & $(-3.66)$ & $(-2.29)$ & $(-2.35)$ & $(-1.32)$ & $(-1.18)$ & $(-0.90)$ & $(-0.22)$ & $(-0.21)$ \\
\hline \multirow[t]{2}{*}{ Insiders } & $-0.0393^{* *}$ & & & & & -0.0107 & & & & & 0.0583 & & & & \\
\hline & $(-2.49)$ & & & & & $(-0.22)$ & & & & & $(1.05)$ & & & & \\
\hline \multirow[t]{2}{*}{ DIxInsiders } & $0.000527^{* *}$ & & & & & -0.0000102 & & & & & -0.000853 & & & & \\
\hline & $(2.22)$ & & & & & $(-0.02)$ & & & & & $(-1.27)$ & & & & \\
\hline \multirow[t]{2}{*}{ Inst } & & -0.00327 & & & & & -0.00150 & & & & & 0.00185 & & & \\
\hline & & $(-0.66)$ & & & & & $(-0.18)$ & & & & & $(0.20)$ & & & \\
\hline DIXInst & & $(0.72)$ & & & & & $(0.28)$ & & & & & $(-0.08)$ & & & \\
\hline \multirow[t]{2}{*}{ Gown } & & & -0.0106 & & & & & $0.0207 *$ & & & & & 0.0179 & & \\
\hline & & & $(-1.33)$ & & & & & $(1.69)$ & & & & & $(1.46)$ & & \\
\hline \multirow[t]{2}{*}{ DIxGown } & & & 0.0000244 & & & & & -0.0000476 & & & & & -0.000125 & & \\
\hline & & & $(0.25)$ & & & & & $(-0.33)$ & & & & & $(-0.81)$ & & \\
\hline \multirow[t]{2}{*}{ Block } & & & & $-0.00895^{* *}$ & & & & & 0.00847 & & & & & 0.0123 & \\
\hline & & & & $(-2.00)$ & & & & & $(1.18)$ & & & & & $(1.19)$ & \\
\hline \multirow[t]{2}{*}{ DIxBlock } & & & & $0.000115^{*}$ & & & & & -0.0000605 & & & & & -0.000130 & \\
\hline & & & & (1.82) & & & & & $(-0.59)$ & & & & & $(-0.91)$ & \\
\hline HHI & & & & & $(-1.50)$ & & & & & $(0.57)$ & & & & & $(0.96)$ \\
\hline \multirow[t]{2}{*}{ DIxHHI } & & & & & 0.000157 & & & & & -0.0000832 & & & & & -0.000251 \\
\hline & & & & & $(1.38)$ & & & & & $(-0.49)$ & & & & & $(-1.18)$ \\
\hline \multirow[t]{2}{*}{ PBV } & 0.0250 & 0.0215 & 0.00787 & 0.0217 & 0.0173 & -0.0575 & -0.0567 & -0.0407 & -0.0542 & -0.0546 & -0.0766 & -0.0493 & -0.0449 & -0.0475 & -0.0498 \\
\hline & $(0.65)$ & $(0.54)$ & $(0.21)$ & $(0.56)$ & $(0.43)$ & $(-1.02)$ & $(-0.99)$ & $(-0.74)$ & $(-0.94)$ & $(-0.94)$ & $(-1.31)$ & $(-0.91)$ & $(-0.84)$ & $(-0.89)$ & $(-0.93)$ \\
\hline \multirow[t]{2}{*}{ TA } & 0.0199 & 0.0321 & 0.0331 & 0.0278 & 0.0273 & 0.00230 & -0.00622 & -0.00689 & -0.00138 & -0.00514 & -0.0193 & -0.0449 & -0.0411 & -0.0352 & -0.0409 \\
\hline & $(0.48)$ & $(0.79)$ & $(0.80)$ & $(0.66)$ & $(0.64)$ & $(0.04)$ & $(-0.11)$ & $(-0.11)$ & $(-0.02)$ & $(-0.09)$ & $(-0.43)$ & $(-1.05)$ & $(-0.94)$ & $(-0.80)$ & $(-0.94)$ \\
\hline Tier1 & -0.0137 & -0.00774 & -0.00799 & -0.00772 & -0.00692 & 0.00657 & 0.00827 & 0.00779 & 0.00743 & 0.00791 & -0.00710 & -0.0145 & -0.0160 & -0.0156 & -0.0129 \\
\hline & $(-1.37)$ & $(-0.77)$ & $(-0.79)$ & $(-0.77)$ & $(-0.71)$ & $(0.25)$ & $(0.31)$ & $(0.30)$ & $(0.28)$ & $(0.30)$ & $(-0.33)$ & $(-0.65)$ & $(-0.71)$ & $(-0.69)$ & $(-0.57)$ \\
\hline Growth & $0.0272 * * *$ & $0.0306^{* * *}$ & $0.0325^{* * *}$ & $0.0305^{* * *}$ & $0.0306^{* * *}$ & $0.0991^{* * *}$ & $0.0988^{* * *}$ & $0.0974^{* * *}$ & $0.0997^{* * *}$ & $0.0968^{* * *}$ & $0.108^{* * * *}$ & $0.101^{* * *}$ & $0.101^{* * *}$ & $0.101^{* * *}$ & $0.102 * * *$ \\
\hline & $(2.97)$ & (2.98) & (3.21) & (3.05) & $(2.95)$ & (3.47) & $(3.42)$ & (3.36) & $(3.45)$ & (3.33) & $(3.16)$ & $(2.94)$ & $(2.91)$ & $(2.96)$ & $(2.94)$ \\
\hline Interest & 0.00708 & 0.0141 & 0.0165 & 0.0135 & 0.0145 & $-0.0557^{* * *}$ & $-0.0535^{* * *}$ & $-0.0592 * * *$ & $-0.0540^{* * *}$ & $-0.0516^{* *}$ & -0.0203 & -0.0281 & -0.0307 & -0.0281 & -0.0283 \\
\hline & $(0.71)$ & $(1.38)$ & $(1.64)$ & $(1.34)$ & $(1.42)$ & $(-2.97)$ & $(-2.65)$ & $(-3.01)$ & $(-2.69)$ & $(-2.55)$ & $(-1.01)$ & $(-1.36)$ & $(-1.50)$ & $(-1.35)$ & $(-1.37)$ \\
\hline Inflation & 0.00202 & 0.00420 & 0.00299 & 0.00429 & 0.00141 & -0.0233 & -0.0178 & -0.0193 & -0.0170 & -0.0149 & 0.00885 & 0.0114 & 0.0107 & 0.0115 & 0.0101 \\
\hline & $(0.17)$ & $(0.36)$ & $(0.26)$ & $(0.37)$ & $(0.12)$ & $(-1.14)$ & $(-0.84)$ & $(-0.92)$ & $(-0.81)$ & $(-0.68)$ & $(0.41)$ & $(0.51)$ & $(0.48)$ & $(0.52)$ & $(0.46)$ \\
\hline Covdep & 0.0414 & 0.0341 & 0.0422 & 0.0370 & 0.0370 & $0.203^{* * *}$ & $0.196^{* * *}$ & $0.179^{* * *}$ & $0.190^{* * *}$ & $0.193^{* * *}$ & $0.210^{* * *}$ & $0.217^{* * *}$ & $0.209^{* * *}$ & $0.210^{* * *}$ & $0.213^{* * *}$ \\
\hline & $(1.47)$ & $(1.18)$ & $(1.49)$ & $(1.29)$ & $(1.27)$ & $(3.48)$ & $(3.30)$ & $(3.19)$ & $(3.22)$ & $(3.24)$ & $(3.14)$ & $(3.23)$ & $(3.08)$ & $(3.17)$ & $(3.17)$ \\
\hline Intercept & $3.952^{* * *}$ & $3.717^{* * *}$ & $3.676^{* * *}$ & $4.086^{* * *}$ & $3.936^{* * *}$ & $-1.362^{*}$ & -1.173 & $-1.385^{*}$ & $-1.573^{*}$ & $-1.402^{*}$ & $1.356^{*}$ & $1.768^{* *}$ & $1.592^{* *}$ & 1.235 & $1.328^{*}$ \\
\hline & $(7.15)$ & $(7.37)$ & $(6.40)$ & $(7.06)$ & $(6.40)$ & $(-1.75)$ & $(-1.37)$ & $(-1.79)$ & $(-1.80)$ & $(-1.70)$ & (1.88) & $(2.37)$ & $(2.12)$ & (1.35) & (1.66) \\
\hline R-square & 0.238 & 0.197 & 0.203 & 0.197 & 0.202 & 0.128 & 0.125 & 0.135 & 0.130 & 0.121 & 0.118 & 0.125 & 0.129 & 0.129 & 0.118 \\
\hline F-stat. & $13.38^{* * *}$ & $10.01^{* * *}$ & $12.23^{* * *}$ & $10.00^{* * *}$ & $10.58^{* * *}$ & $7.160^{* * *}$ & $5.880^{* * *}$ & $6.203^{* * *}$ & $6.111^{* * *}$ & $5.487^{* * *}$ & $8.092 * * *$ & $5.427 * * *$ & $5.975^{* * *}$ & $5.703^{* * * *}$ & $4.952 * * *$ \\
\hline Significance te & & & & & & & & & & & & & & & \\
\hline DI+DIxIown & 0.03 & & & & & $13.16^{* * *}$ & & & & & 2.34 & & & & \\
\hline DI+DIxInst & & 0.06 & & & & & $8.19 * * *$ & & & & & 1.44 & & & \\
\hline DI+DIxGown & & & 0.04 & & & & & $13.85^{* * *}$ & & & & & 0.88 & & \\
\hline DI+DIxBlock & & & 0.07 & 1.35 & & & & & $5.42 * *$ & & & & & 0.06 & \\
\hline DI+DIxHHI & & & & & 0.39 & & & & & $5.80^{* *}$ & & & & & 0.06 \\
\hline
\end{tabular}

Table A.2 reports within estimations. T-statistics are in parentheses and corrected for heteroskedasticity following White's methodology. Explanatory variables are disclosure index (DI), insider ownerships (Insiders), institutional ownerships (Inst), block ownerships (Block), Herfindahl-Hirschman Index (HHI) and control variables. We also include interaction terms between disclosure and insider ownerships (DIxInsiders), institution ownerships (DIxinst), government ownerships (DIxgown), block ownerships (DIxblock), ownership concentration (DIxHHi) and the control variables (PBV, Size, Tier 1 capital ratio, coverage of insurance deposits, GDP growth, interest rate, inflation). NPL-to-Cap = ratio of non-performing loan to gross loan divided by ratio of capital asset to total assets (TA), SDROA = the standard deviation of ROA based on two previous years data, SDROE $=$ standard deviation of return on equity. The values of dependent variables NPL to Cap, SDROA and SDROE are in natural logarithm. Independent variables are in decimals except described otherwise. Significance test is the test of the null hypothesis that the sum of the coefficients of disclosure and the interaction term do not have joint impacts on risk. Superscripts $* * *, * *$, and $*$ denotes statistical significant at the $.01, .05$ and .10 levels respectively. 
Table A.3 Robustness tests: The impact of disclosure components on bank risk

\begin{tabular}{|c|c|c|c|c|c|c|c|c|c|c|c|c|c|c|c|c|c|c|}
\hline \multirow{2}{*}{$\begin{array}{c}\text { Dep. var. } \\
\text { Model }\end{array}$} & \multicolumn{6}{|c|}{ Z-Score } & \multicolumn{6}{|c|}{ Z-Score 1} & \multicolumn{6}{|c|}{ Z-Score 2} \\
\hline & (1) & (2) & (3) & (4) & (5) & (6) & (1) & (2) & (3) & (4) & (5) & (6) & (1) & (2) & (3) & (4) & (5) & (6) \\
\hline \multirow[t]{2}{*}{ DILoan } & $0.0119^{* *}$ & & & & & & $0.00658^{*}$ & & & & & & $0.0120^{* * *}$ & & & & & \\
\hline & $(2.51)$ & & & & & & $(1.66)$ & & & & & & $(2.55)$ & & & & & \\
\hline \multirow[t]{2}{*}{ DIEA } & & $0.00759^{* * *}$ & & & & & & $0.00664 * * *$ & & & & & & $0.00723^{* * *}$ & & & & \\
\hline & & (3.49) & & & & & & $(3.20)$ & & & & & & (3.40) & & & & \\
\hline \multirow[t]{2}{*}{ DIDep } & & & 0.00623 & & & & & & -0.000406 & & & & & & 0.00672 & & & \\
\hline & & & $(1.32)$ & & & & & & $(-0.12)$ & & & & & & $(1.48)$ & & & \\
\hline \multirow[t]{2}{*}{ DIFund } & & & & $-0.00552 *$ & & & & & & $-0.00665^{* *}$ & & & & & & -0.00493 & & \\
\hline & & & & $(-1.77)$ & & & & & & $(-2.11)$ & & & & & & $(-1.64)$ & & \\
\hline \multirow[t]{2}{*}{ DIMemo } & & & & & $0.0115^{* * *}$ & & & & & & 0.00585 & & & & & & $0.0118^{* * *}$ & \\
\hline & & & & & $(3.28)$ & & & & & & $(1.57)$ & & & & & & $(3.42)$ & \\
\hline \multirow[t]{2}{*}{ DIIS } & & & & & & $0.0103^{* *}$ & & & & & & 0.00618 & & & & & & $0.0100^{* * *}$ \\
\hline & & & & & & $(2.32)$ & & & & & & $(1.57)$ & & & & & & $(2.21)$ \\
\hline \multirow[t]{2}{*}{ PBV } & 0.0517 & 0.0488 & 0.0592 & 0.0667 & 0.0432 & 0.0432 & $0.157^{* *}$ & $0.145 * *$ & $0.160^{* * *}$ & $0.175^{* *}$ & $0.153^{* *}$ & $0.153^{* * *}$ & 0.0540 & 0.0515 & 0.0617 & 0.0680 & 0.0452 & 0.0460 \\
\hline & $(0.79)$ & $(0.76)$ & $(0.90)$ & (1.01) & $(0.68)$ & $(0.68)$ & $(2.21)$ & $(2.00)$ & $(2.27)$ & $(2.43)$ & $(2.15)$ & $(2.16)$ & $(0.86)$ & $(0.84)$ & $(0.97)$ & $(1.07)$ & $(0.73)$ & $(0.75)$ \\
\hline \multirow[t]{2}{*}{ Size } & -0.0356 & -0.0221 & -0.0363 & -0.0220 & -0.0379 & -0.0333 & 0.0316 & 0.0345 & 0.0392 & 0.0382 & 0.0300 & 0.0332 & -0.0347 & -0.0212 & -0.0363 & -0.0213 & -0.0373 & -0.0321 \\
\hline & $(-0.51)$ & $(-0.32)$ & $(-0.53)$ & $(-0.31)$ & $(-0.57)$ & $(-0.48)$ & $(0.37)$ & $(0.42)$ & $(0.45)$ & $(0.45)$ & $(0.36)$ & $(0.39)$ & $(-0.51)$ & $(-0.31)$ & $(-0.55)$ & $(-0.31)$ & $(-0.57)$ & $(-0.47)$ \\
\hline \multirow[t]{2}{*}{ Tier1 } & 0.0423 & 0.0376 & 0.0441 & 0.0368 & 0.0358 & 0.0394 & 0.00314 & 0.000822 & 0.00121 & -0.00423 & 0.000125 & 0.00109 & 0.0373 & 0.0328 & 0.0393 & 0.0323 & 0.0307 & 0.0345 \\
\hline & $(1.42)$ & $(1.23)$ & $(1.48)$ & $(1.22)$ & $(1.19)$ & $(1.35)$ & $(0.10)$ & $(0.03)$ & $(0.04)$ & $(-0.13)$ & $(0.00)$ & $(0.04)$ & $(1.29)$ & $(1.10)$ & $(1.36)$ & $(1.09)$ & $(1.05)$ & (1.21) \\
\hline \multirow[t]{2}{*}{ Growth } & $-0.116^{* * *}$ & $-0.120^{* * *}$ & $-0.123^{* * *}$ & $-0.121 * * *$ & $-0.116^{* * *}$ & $-0.122 * * *$ & $-0.116^{* * * *}$ & $-0.118^{* * *}$ & $-0.121 * * *$ & $-0.118 * * *$ & $-0.116^{* * * *}$ & $-0.119 * * *$ & $-0.110^{* * *}$ & $-0.115 * * *$ & $-0.117 * * *$ & $-0.115 * * *$ & $-0.110^{* * *}$ & $-0.117^{* * * *}$ \\
\hline & $(-3.77)$ & $(-4.00)$ & $(-3.87)$ & $(-3.85)$ & $(-3.78)$ & $(-3.87)$ & $(-3.46)$ & $(-3.62)$ & $(-3.56)$ & $(-3.54)$ & $(-3.47)$ & $(-3.52)$ & $(-3.70)$ & $(-3.92)$ & $(-3.81)$ & $(-3.80)$ & $(-3.70)$ & $(-3.82)$ \\
\hline \multirow[t]{2}{*}{ Interest } & $0.0604 * * *$ & $0.0515 * *$ & $0.0635^{* * * *}$ & $0.0570^{* * * *}$ & $0.0546^{* * *}$ & $0.0590^{* * * *}$ & $0.0778^{* * * *}$ & $0.0687^{* * *}$ & $0.0770^{* * * *}$ & $0.0745^{* * * *}$ & $0.0746^{* * * *}$ & $0.0777^{* * * *}$ & $0.0592^{* * * *}$ & $0.0507 * *$ & $0.0626^{* * * *}$ & $0.0560^{* * * *}$ & $0.0532^{* * *}$ & $0.0578 * * *$ \\
\hline & $(2.83)$ & $(2.50)$ & $(2.95)$ & $(2.75)$ & $(2.60)$ & $(2.78)$ & (3.23) & $(2.91)$ & $(3.25)$ & $(3.11)$ & (3.15) & $(3.29)$ & $(2.86)$ & $(2.55)$ & $(3.02)$ & $(2.80)$ & $(2.64)$ & $(2.82)$ \\
\hline \multirow[t]{2}{*}{ Inflation } & 0.0279 & 0.0205 & 0.0324 & 0.0333 & 0.0158 & 0.0220 & 0.0349 & 0.0253 & 0.0366 & $0.0409^{*}$ & 0.0286 & 0.0319 & 0.0267 & 0.0198 & 0.0313 & 0.0319 & 0.0142 & 0.0211 \\
\hline & $(1.36)$ & $(1.03)$ & (1.62) & (1.63) & $(0.75)$ & $(1.06)$ & $(1.44)$ & $(1.10)$ & (1.53) & $(1.69)$ & $(1.15)$ & $(1.28)$ & $(1.33)$ & $(1.02)$ & $(1.60)$ & (1.59) & $(0.69)$ & (1.04) \\
\hline \multirow[t]{2}{*}{ Covdep } & $-0.255 * * *$ & $-0.237 * * *$ & $-0.252 * * *$ & $-0.248 * * *$ & $-0.221 * * *$ & $-0.254 * * *$ & $-0.265 * * *$ & $-0.245 * * *$ & $-0.262 * * *$ & $-0.256 * * *$ & $-0.246 * * *$ & $-0.264 * * *$ & $-0.245^{* * *}$ & $-0.227^{* * * *}$ & $-0.242 * * *$ & $-0.238^{* * *}$ & $-0.210^{* * *}$ & $-0.244 * * *$ \\
\hline & $(-4.21)$ & $(-3.75)$ & $(-4.20)$ & $(-4.13)$ & $(-3.66)$ & $(-4.15)$ & $(-3.82)$ & $(-3.42)$ & $(-3.75)$ & $(-3.71)$ & $(-3.49)$ & $(-3.76)$ & $(-4.13)$ & $(-3.68)$ & $(-4.12)$ & $(-4.05)$ & $(-3.57)$ & $(-4.07)$ \\
\hline \multirow[t]{2}{*}{ Intercept } & $3.817^{* * *}$ & $3.948^{* * * *}$ & $3.995^{* * *}$ & $4.665^{* * * *}$ & $3.420^{* * *}$ & $3.425^{* * * *}$ & 1.135 & 1.171 & 1.394 & $1.916^{* *}$ & 0.958 & 0.867 & $3.714 * * *$ & $3.863^{* * * *}$ & $3.876^{* * *}$ & $4.521^{* * * *}$ & $3.300^{* * *}$ & $3.348^{* * * *}$ \\
\hline & $(4.58)$ & $(4.85)$ & $(4.95)$ & $(5.60)$ & $(4.00)$ & (3.66) & $(1.21)$ & $(1.29)$ & (1.49) & $(2.03)$ & (1.01) & $(0.90)$ & $(4.50)$ & $(4.81)$ & $(4.88)$ & $(5.48)$ & $(3.89)$ & (3.57) \\
\hline $\mathrm{N}$ & 1030 & 1030 & 1030 & 1030 & 1030 & 1030 & 944 & 944 & 944 & 944 & & & & & & & 1030 & \\
\hline R-squared & 0.139 & 0.146 & 0.130 & 0.135 & 0.146 & 0.138 & 0.140 & 0.149 & 0.137 & 0.146 & 0.140 & 0.140 & 0.140 & 0.146 & 0.131 & 0.134 & 0.149 & 0.138 \\
\hline F-statistic & $7371^{* * *}$ & $8.222 * * *$ & $7.141^{* * *}$ & $7.810^{* * * *}$ & $7.630^{* * *}$ & $7.116^{* * *}$ & $6682 * * *$ & $7.379 * * *$ & $6.224 * * *$ & $6.995^{* * *}$ & $6667 * * *$ & $6388 * * *$ & $7675^{* * * *}$ & $8404^{* * * *}$ & $7.412 * * *$ & $7.978^{* * * *}$ & $7.926 * * *$ & $7283 * *$ \\
\hline
\end{tabular}

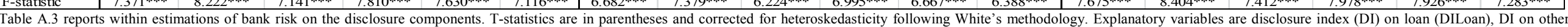

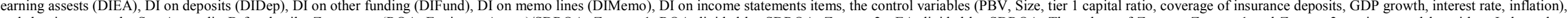

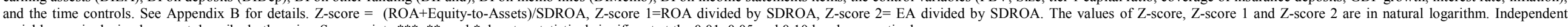
variables are in decimals except described otherwise. Superscripts $* * * * *$, and $*$ denotes statistical significant at the $0.01,0.05$ and 0.10 levels respectively. 
Table A.3 Robustness tests: The impact of disclosure components on bank risk (cont'd)

\begin{tabular}{|c|c|c|c|c|c|c|c|c|c|c|c|c|c|c|c|c|c|c|}
\hline \multirow{2}{*}{$\begin{array}{c}\text { Dep. var. } \\
\text { Model }\end{array}$} & \multicolumn{6}{|c|}{ NPL-to-Cap } & \multicolumn{6}{|c|}{ SDROA } & \multicolumn{6}{|c|}{ SDROE } \\
\hline & (1) & (2) & (3) & (4) & (5) & (6) & (1) & (2) & (3) & (4) & (5) & (6) & (1) & (2) & (3) & (4) & (5) & (6) \\
\hline \multirow[t]{2}{*}{ DILoan } & -0.000291 & & & & & & $-0.00943 * *$ & & & & & & $\begin{array}{l}-0.00439 \\
\end{array}$ & & & & & \\
\hline & $(-0.12)$ & & & & & & $(-2.07)$ & & & & & & $(-0.88)$ & & & & & \\
\hline \multirow[t]{2}{*}{ DIEA } & & 0.000866 & & & & & & $-0.00554 * * *$ & & & & & & $-0.00491 * *$ & & & & \\
\hline & & $(0.87)$ & & & & & & $(-2.66)$ & & & & & & $(-2.13)$ & & & & \\
\hline \multirow[t]{2}{*}{ DIDep } & & & -0.0000464 & & & & & & -0.00481 & & & & & & -0.000870 & & & \\
\hline & & & $(-0.02)$ & & & & & & $(-1.15)$ & & & & & & $(-0.17)$ & & & \\
\hline \multirow[t]{2}{*}{ DIF und } & & & & 0.000404 & & & & & & 0.00440 & & & & & & $0.00665 * * *$ & & \\
\hline & & & & $(0.29)$ & & & & & & $(1.58)$ & & & & & & (2.65) & & \\
\hline \multirow[t]{2}{*}{ DIM emo } & & & & & 0.00337 & & & & & & $-0.0100 * * *$ & & & & & & $-0.00597 *$ & \\
\hline & & & & & $(1.64)$ & & & & & & $(-3.26)$ & & & & & & $(-1.89)$ & \\
\hline \multirow[t]{2}{*}{ DIIS } & & & & & & 0.00322 & & & & & & $-0.00939 * * *$ & & & & & & -0.00492 \\
\hline & & & & & & $(1.09)$ & & & & & & $(-2.70)$ & & & & & & $(-1.56)$ \\
\hline \multirow[t]{2}{*}{ PBV } & 0.0241 & 0.0231 & 0.0239 & 0.0234 & 0.0209 & 0.0205 & -0.0647 & -0.0629 & -0.0706 & -0.0766 & -0.0569 & -0.0563 & -0.0781 & -0.0745 & -0.0803 & -0.0936 & -0.0723 & -0.0728 \\
\hline & $(0.63)$ & $(0.61)$ & $(0.63)$ & $(0.62)$ & $(0.55)$ & $(0.55)$ & $(-1.11)$ & $(-1.10)$ & $(-1.21)$ & $(-1.30)$ & $(-0.99)$ & $(-0.99)$ & $(-1.33)$ & $(-1.29)$ & $(-1.37)$ & $(-1.55)$ & $(-1.24)$ & $(-1.24)$ \\
\hline \multirow[t]{2}{*}{ Size } & 0.0196 & 0.0195 & 0.0194 & 0.0189 & 0.0133 & 0.0147 & 0.0180 & 0.00742 & 0.0183 & 0.00727 & 0.0209 & 0.0173 & -0.0130 & -0.0186 & -0.0154 & -0.0193 & -0.0102 & -0.0127 \\
\hline & $(0.49)$ & $(0.48)$ & $(0.48)$ & $(0.47)$ & $(0.34)$ & $(0.37)$ & $(0.26)$ & $(0.11)$ & $(0.27)$ & $(0.10)$ & $(0.31)$ & $(0.25)$ & $(-0.30)$ & $(-0.44)$ & $(-0.35)$ & $(-0.43)$ & $(-0.23)$ & $(-0.29)$ \\
\hline \multirow[t]{2}{*}{ Tier1 } & -0.0132 & -0.0136 & -0.0132 & -0.0128 & -0.0147 & -0.0139 & 0.00701 & 0.0105 & 0.00567 & 0.0114 & 0.0125 & 0.00952 & -0.00794 & -0.00487 & -0.00807 & -0.00281 & -0.00494 & -0.00676 \\
\hline & $(-1.33)$ & $(-1.38)$ & $(-1.29)$ & $(-1.26)$ & $(-1.47)$ & $(-1.43)$ & $(0.27)$ & $(0.40)$ & $(0.22)$ & $(0.44)$ & $(0.48)$ & $(0.38)$ & $(-0.37)$ & $(-0.22)$ & $(-0.37)$ & $(-0.13)$ & $(-0.23)$ & $(-0.31)$ \\
\hline \multirow[t]{2}{*}{ Growth } & $0.0265^{* * *}$ & $0.0271 * * *$ & $0.0267^{* * * *}$ & $0.0264 * * *$ & $0.0287^{* * * *}$ & $0.0268 * * *$ & $0.101 * * *$ & $0.105^{* * * *}$ & $0.107 * * *$ & $0.105 * * *$ & $0.101 * * *$ & $0.106 * * *$ & $0.109^{* * * *}$ & $0.110 * * *$ & $0.112 * * *$ & $0.109 * * *$ & $0.109 * * *$ & $0.112 * * *$ \\
\hline & $(2.91)$ & (2.93) & $(2.87)$ & \begin{tabular}{|l|}
$(2.77)$ \\
\end{tabular} & $(2.99)$ & $(2.87)$ & $(3.50)$ & $(3.68)$ & (3.59) & (3.57) & (3.49) & $(3.59)$ & $(3.19)$ & $(3.26)$ & $(3.24)$ & $(3.18)$ & $(3.18)$ & $(3.24)$ \\
\hline \multirow[t]{2}{*}{ Interest } & 0.00730 & 0.00633 & 0.00727 & 0.00744 & 0.00540 & 0.00669 & $-0.0585 * * *$ & $-0.0520^{* * *}$ & $-0.0609 * * *$ & $-0.0558^{* * *}$ & $-0.0535^{* * *}$ & $-0.0573 * * *$ & -0.0218 & -0.0162 & -0.0220 & -0.0188 & -0.0190 & -0.0212 \\
\hline & $(0.75)$ & $(0.64)$ & $(0.73)$ & $(0.76)$ & $(0.57)$ & $(0.73)$ & $(-3.03)$ & $(-2.77)$ & $(-3.17)$ & $(-2.95)$ & $(-2.82)$ & $(-3.00)$ & $(-1.08)$ & $(-0.83)$ & $(-1.08)$ & $(-0.94)$ & $(-0.94)$ & $(-1.05)$ \\
\hline \multirow[t]{2}{*}{ Inflation } & 0.00258 & 0.00133 & 0.00250 & 0.00238 & -0.00141 & 0.000442 & -0.0318 & -0.0266 & $-0.0353 *$ & $-0.0361 *$ & -0.0211 & -0.0261 & 0.00458 & 0.0104 & 0.00347 & -0.000387 & 0.0114 & 0.00792 \\
\hline & $(0.23)$ & $(0.11)$ & $(0.22)$ & $(0.21)$ & $(-0.13)$ & $(0.04)$ & $(-1.58)$ & $(-1.36)$ & $(-1.82)$ & $(-1.80)$ & $(-1.01)$ & $(-1.28)$ & $(0.22)$ & $(0.48)$ & $(0.17)$ & $(-0.02)$ & $(0.51)$ & $(0.37)$ \\
\hline \multirow[t]{2}{*}{ Covdep } & 0.0410 & 0.0428 & 0.0410 & 0.0406 & $0.0499 *$ & 0.0402 & $0.217^{* * * *}$ & $0.203 * * *$ & $0.214 * * *$ & $0.211^{* * * *}$ & $0.187 * * *$ & $0.216 * * *$ & $0.216^{* * * *}$ & $0.205^{* * * *}$ & $0.215 * * *$ & $0.209 * * *$ & $0.199 * * *$ & $0.216^{* * * *}$ \\
\hline & (1.47) & $(1.52)$ & $(1.46)$ & $(1.45)$ & $(1.79)$ & $(1.44)$ & $(3.73)$ & $(3.39)$ & $(3.72)$ & $(3.66)$ & $(3.24)$ & $(3.69)$ & $(3.26)$ & $(3.04)$ & $(3.23)$ & $(3.17)$ & $(2.99)$ & $(3.23)$ \\
\hline \multirow[t]{2}{*}{ Intercept } & $3.966^{* * *}$ & $3.922 * * *$ & $3.957^{* * * *}$ & $3.926^{* * * *}$ & $3.733 * * *$ & $3.718^{* * * *}$ & $-2.147 * * *$ & $-2.268 * * *$ & $-2.292 * * *$ & $-2.820^{* * * *}$ & $-1.767^{* * *}$ & $-1.736^{* * *}$ & $1.069^{*}$ & $1.101 *$ & 0.948 & 0.413 & $1.341 * *$ & $1.301 * *$ \\
\hline & $(8.33)$ & $(8.43)$ & $(8.15)$ & $(7.87)$ & $(7.69)$ & $(7.10)$ & $(-2.63)$ & $(-2.84)$ & $(-2.93)$ & $(-3.45)$ & $(-2.17)$ & $(-2.04)$ & (1.74) & $(1.92)$ & $(1.51)$ & $(0.70)$ & $(2.23)$ & $(2.11)$ \\
\hline $\mathrm{N}$ & 1027 & 1027 & & & & & & & 1030 & & 1030 & & 1011 & & 1011 & & & 1011 \\
\hline & 0.237 & 0.238 & 0.237 & 0.237 & 0.244 & 0.241 & 0.119 & 0.122 & 0.113 & 0.116 & 0.128 & 0.121 & 0.117 & 0.124 & 0.115 & 0.128 & 0.121 & 0.118 \\
\hline & $184 * *$ & $1962 * *$ & $17570^{* * * *}$ & (1) $832 * * *$ & (2) & $1919^{* * * *}$ & $675 \% * * *$ & $7190 * * *$ & $6507 * * *$ & $6.923 * * *$ & $7256 * * *$ & $65^{5} 1 * *$ & $609 * * * *$ & $6044 * * *$ & $6177^{* * * *}$ & $7100 * * *$ & $6085 * * *$ & 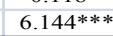 \\
\hline
\end{tabular}

Table A.3 reports within estimations of bank risk on the disclosure components. T-statistics are in parentheses and corrected for heteroskedasticity following White's methodology. Explanatory variables are DI on loan (DILoan), DI on other earning assests (DIEA), DI on assests (DIEA), DI on deposits (DIDep), DI on other funding (DIFund), DI on memo lines (DIMemo), DI on income statements items, the control variables (PBV, Size, tier 1 capital ratio, coverage of insurance deposits, GDP growth, interest rate,
inflation), and the time controls. See Appendix B for details. NPL-to-Cap = ratio of non-performing loan to gross loan divided by ratio of capital asset to total assets, SDROA = the standard deviation of ROA based on two previous years data, SDROE $=$ standard devition of retur. on equity. The values of NPL-to-Cap, SDROA, and SDROE are in natural logarithm. Independent variables are in decimals except described otherwise. Superscripts *** **, and * denotes statistical significant at the $0.01,0.05$ and 0.10 levels respectively. 


\section{Appendix B Variable Definition}

\begin{tabular}{|c|c|c|}
\hline Variable & Description & Source \\
\hline \multicolumn{3}{|c|}{ Panel A: Dependent variables } \\
\hline Z score & $\begin{array}{l}\text { Return on average assets (ROA) plus equity to total assets ratio, } \\
\text { divided by the standard deviation of last three-year ROA }\end{array}$ & Bankscope \\
\hline Z score 1 & $\begin{array}{l}\text { Return on average assets (ROA) divided by the standard } \\
\text { deviation of last three-year ROA }\end{array}$ & Bankscope \\
\hline Z score 2 & $\begin{array}{l}\text { Equity to total assets ratio, divided by the standard deviation of } \\
\text { last three-year ROA }\end{array}$ & Bankscope \\
\hline NPL to Cap & $\begin{array}{l}\text { Bank non performing loan to total loans divided by bank capital } \\
\text { to total assets }\end{array}$ & Bankscope \\
\hline SDROA & Standard deviation of last three-year return on average assets & Bankscope \\
\hline SDROE & Standard deviation of last three-year return on average equity & Bankscope \\
\hline \multicolumn{3}{|c|}{ Panel B: Independent variables } \\
\hline Disclosure index (DI) & $\begin{array}{l}\text { The disclosure index based on } 17 \text { items as Bauman and Nier } \\
\text { (2004) see Appendix C for details }\end{array}$ & Bankscope \\
\hline $\begin{array}{l}\text { Insider ownerships } \\
\text { (Insiders) }\end{array}$ & Total fraction of shares owned by directors or supervisors & Bankscope \\
\hline $\begin{array}{l}\text { Government ownerships } \\
\text { (Gown) }\end{array}$ & Total fraction of shares owned by government institution/bodies. & Bankscope \\
\hline $\begin{array}{l}\text { Institution ownerships } \\
\text { (Inst) }\end{array}$ & Total fraction of shares owned by institutions & Bankscope \\
\hline Block ownerships (Block) & $\begin{array}{l}\text { Total fraction of shares owned by investors with } 5 \% \text { or more } \\
\text { shareholdings }\end{array}$ & Bankscope \\
\hline $\begin{array}{l}\text { Herfindahl-Hirschman } \\
\text { Index (HHI) }\end{array}$ & $\begin{array}{l}\text { Herfindahl-Hirschman index of share ownerships, as follows: } \\
\mathrm{HHI}=\frac{\sum_{i=1}^{n} \mathrm{~s}^{2} \mathrm{i}_{\mathrm{i}}}{100} \text {, where } \mathrm{s}_{\mathrm{i}} \text { is the percentage of ownerships } \\
\text { characteristic } i \text { in the bank }\end{array}$ & Datastream \\
\hline Price to Book ratio (PBV) & Market value of equity divided by book value of equity & Bankscope \\
\hline Tier 1 capital ratio & Tier-1 capital divided by risk weighted assets & Bankscope \\
\hline Size (TA) & The natural logarithm of book value of total assets & Bankscope \\
\hline GDP growth (Growth) & Annual real GDP growth rate & $\begin{array}{l}\text { World } \\
\text { Development } \\
\text { Indicator (WDI) }\end{array}$ \\
\hline Real interest rate & Real interest rate & WDI \\
\hline Inflation rate & Inflation rate & WDI \\
\hline Covdep & $\begin{array}{l}\text { The natural log value of }(1+\text { coverage deposits }) \text {, where coverage } \\
\text { deposits is the ratio of the maximum deposit insurance coverage } \\
\text { limit per deposit per capita }\end{array}$ & $\begin{array}{l}\text { Authors'calculation } \\
\text { based on the data } \\
\text { from Demirgüç- } \\
\text { Kunt et al. (2005), } \\
\text { updated for Asia }\end{array}$ \\
\hline Year dummy & $\begin{array}{l}\text { Six individual dummy variables which equals } \\
\text { either one or zero for each year from } 2005 \text { to } 2010 \\
\text { with } 2004 \text { being the excluded year. }\end{array}$ & Authors'calculation \\
\hline
\end{tabular}


Appendix C Composite Disclosure Index

\begin{tabular}{|c|c|c|c|}
\hline \multirow{2}{*}{ Dimension } & \multicolumn{2}{|r|}{ Sub Index } & \multirow[t]{2}{*}{ Categories } \\
\hline & & & \\
\hline \multirow[t]{5}{*}{ Loans } & $\mathrm{S} 1$ & Loans by maturity & $\begin{array}{l}<3 \text { months, } 3-6 \text { months, } 6 \text { months }-1 \text { year, } 1-5 \\
\text { years, }>5 \text { years }\end{array}$ \\
\hline & $\mathrm{S} 2$ & Loans by type & $\begin{array}{l}\text { loans to municipalities/government, mortgages, } \\
\text { lease, other loans }\end{array}$ \\
\hline & $\mathrm{S} 3$ & Loans by counterparty & $\begin{array}{l}\text { loans to group companies, loans to other } \\
\text { corporate, loans to banks }\end{array}$ \\
\hline & S4 & Problem loans & total problems loans \\
\hline & S5 & Problem loans by type & overdue, restructured, other non-performing \\
\hline \multirow[t]{3}{*}{$\begin{array}{l}\text { Other earning } \\
\text { as sets }\end{array}$} & S6 & Securities by type & $\begin{array}{l}\text { detailed breakdown: T-bills, other bills, bonds, } \\
\text { CDs, equity investments, other investments }\end{array}$ \\
\hline & & & $\begin{array}{l}\text { coarse breakdown: government securities, other } \\
\text { lis ted securities, non-listed securities }\end{array}$ \\
\hline & S7 & $\begin{array}{l}\text { Securities by holding } \\
\text { purpose }\end{array}$ & inves tment securities, trading securities \\
\hline \multicolumn{4}{|l|}{ Liabilities } \\
\hline \multirow[t]{2}{*}{ Deposits } & S8 & Deposits by maturity & $\begin{array}{l}\text { demand savings, }<3 \text { months, } 3-6 \text { months, } 6 \\
\text { months }-1 \text { year, } 1-5 \text { years, }>5 \text { years }\end{array}$ \\
\hline & S9 & $\begin{array}{l}\text { Deposits by type of } \\
\text { customer }\end{array}$ & bank deposits, municipal/government \\
\hline \multirow[t]{2}{*}{ Other funding } & S10 & Money market funding & total money market funding \\
\hline & S11 & Long-term funding & $\begin{array}{l}\text { convertible bonds, martgage bonds, other } \\
\text { bonds, subordinated debt, hybrid capital }\end{array}$ \\
\hline \multicolumn{4}{|r|}{ 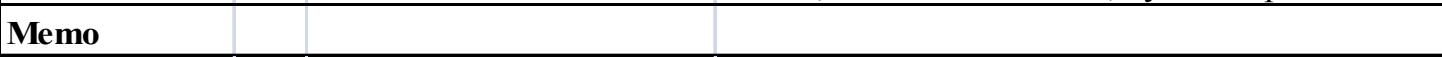 } \\
\hline & S12 & Reserve & loan loss reserves (memo) \\
\hline & S13 & Capital & $\begin{array}{l}\text { Total capital ratio, tier } 1 \text { ratio, total capital, tier } 1 \\
\text { capital }\end{array}$ \\
\hline & S14 & Continget liabilities & total contingent liabilities \\
\hline & $\mathrm{S} 15$ & Off Balance Sheet & Off balance sheet items \\
\hline \multicolumn{4}{|c|}{\begin{tabular}{|l|l} 
Income Statement & \\
\end{tabular}} \\
\hline & S16 & Non interest income & $\begin{array}{l}\text { net commission income, net fee income, net } \\
\text { trading income }\end{array}$ \\
\hline & S17 & Loan loss provisions & Loan loss provisions \\
\hline
\end{tabular}

Source: Nier (2005) 